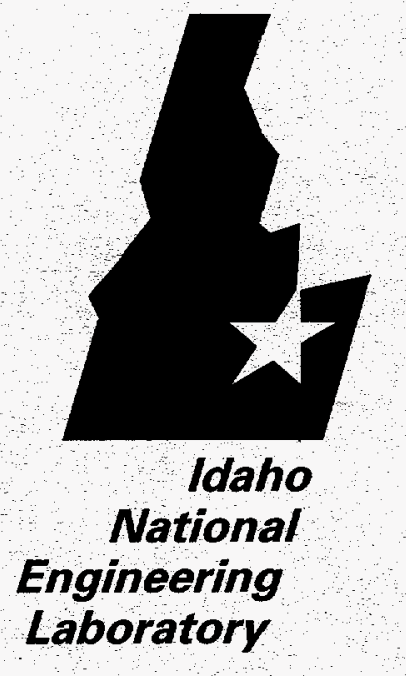

W. D. Richins
INEL - $96 / 0272$

July 1996

\title{
Impact and Structural Analysis of the INEL 55 Gallon Recycled Shielded Storage Container
}

$$
\begin{aligned}
& \text { DEC } 19 \text { is } \\
& \text { OSTI }
\end{aligned}
$$

DISTRIBUTION OF THIS DOCUMENT IS UNLMMITED 


\section{DISCLAIMER}

This report was prepared as an account of work sponsored by an agency of the United States Government. Neither the United States Government nor any agency thereof, nor any of their employees, makes any warranty, express or implied, or assumes any legal liability or responsibility for the accuracy, completeness, or usefulness of any information, apparatus, product, or process disclosed, or represents that its use would not infringe privately owned rights. Reference herein to any specific commercial product, process, or service by trade name, trademark, manufacturer, or otherwise does not necessarily constitute or imply its endorsement, recommendation, or favoring by the United States Government or any agency thereof. The views and opinions of authors expressed herein do not necessarily state or reflect those of the United States Government or any agency thereof. 


\section{DISCLAIMER}

Portions of this document may be illegible in electronic image products. Images are produced from the best available original document. 
INEL - $96 / 0272$

\title{
Impact and Structural Analysis of the INEL 55 Gallon Recycled Shielded Storage Container
}

\author{
W. D. Richins
}

July 1996

\section{Idaho National Engineering Laboratory Lockheed Martin Idaho Technologies Co. Idaho Falls, Idaho $\mathbf{8 3 4 1 5}$}

Prepared for the Division of Engineering Office of Nuclear Regulatory Research U.S. Nuclear Regulatory Commission Washington, D.C. 20555 Under U.S. Department of Energy DOE Operations Office, Idaho Contract DE-AC07-94ID13223 Job Code: A6389 


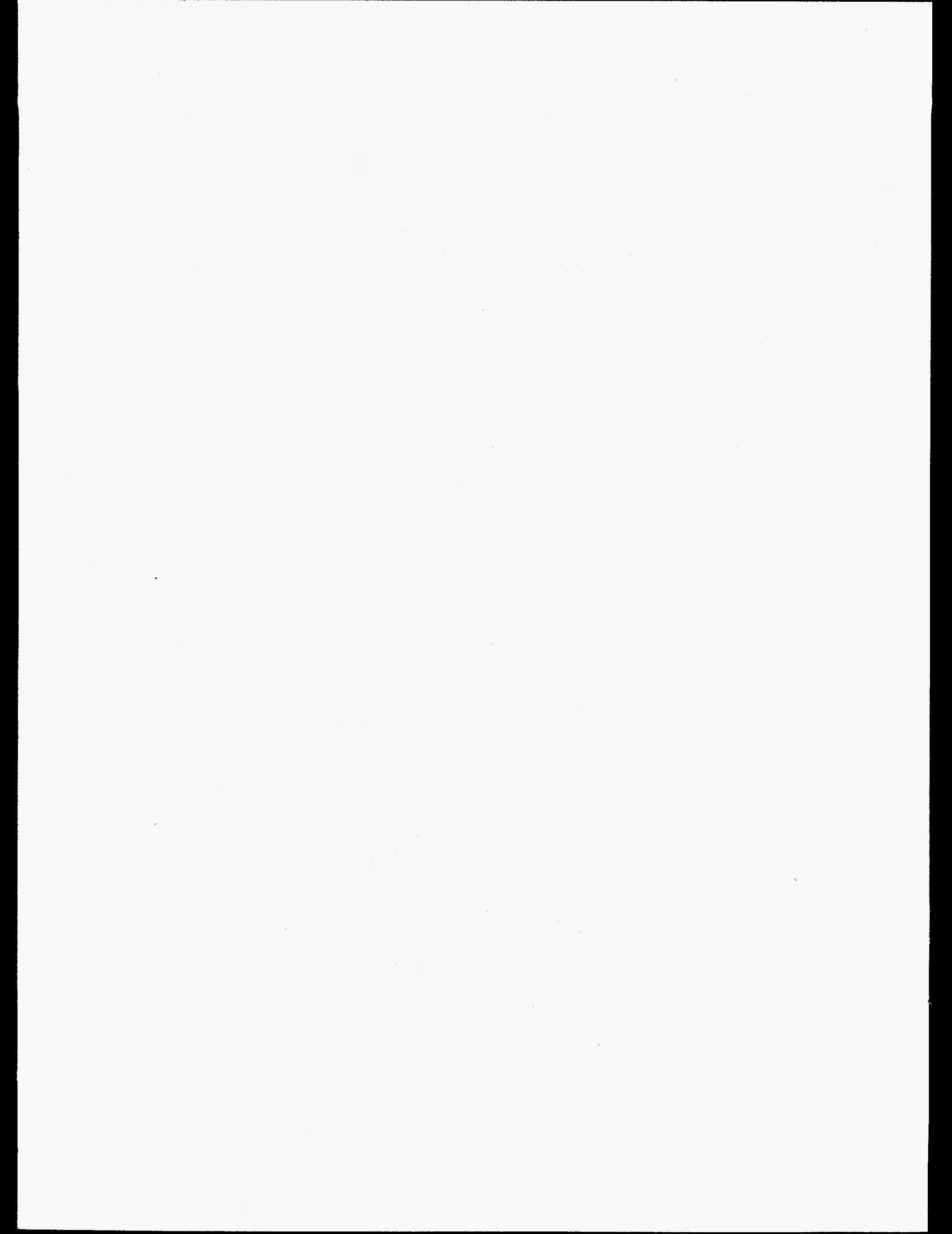




\begin{abstract}
The INEL Recycled Shielded Storage Containers (RSSC) are designed primarily for the transportation and storage of mixed RH -TRU solid waste using recycled, potentially contaminated lead and stainless steel construction materials. Two versions of the RSSC have been developed accommodating either 30 or 55 gallon drums. This report addresses the structural qualification of the 55 gallon version of the RSSC to DOT 7A Type A requirements. The controlling qualification test is a $4 \mathrm{ft}$ drop onto a rigid surface. During and after this test, the container contents must remain within the container and shielding must not be reduced. The container is also designed to withstand stacking, internal pressure, lifting loads, tiedown failure, penetration, and a range of temperatures.

Nonlinear dynamic finite element analyses were performed using a range of material properties. Loads in the major connections and strains in the stainless steel and lead were monitored as a function of time during impact analyses for three simulated drop orientations. Initial results were used to develop the final design. For the final design, the stainless steel and lead have maximum strains well below ultimate levels except at an impact corner where additional deformation is acceptable. The predicted loads in the connections indicate that some yielding will occur but the containment and shielding will remain intact. The results presented here provide assurance that the container will pass the DOT 7A Type A drop tests as well as the other structural requirements.
\end{abstract}




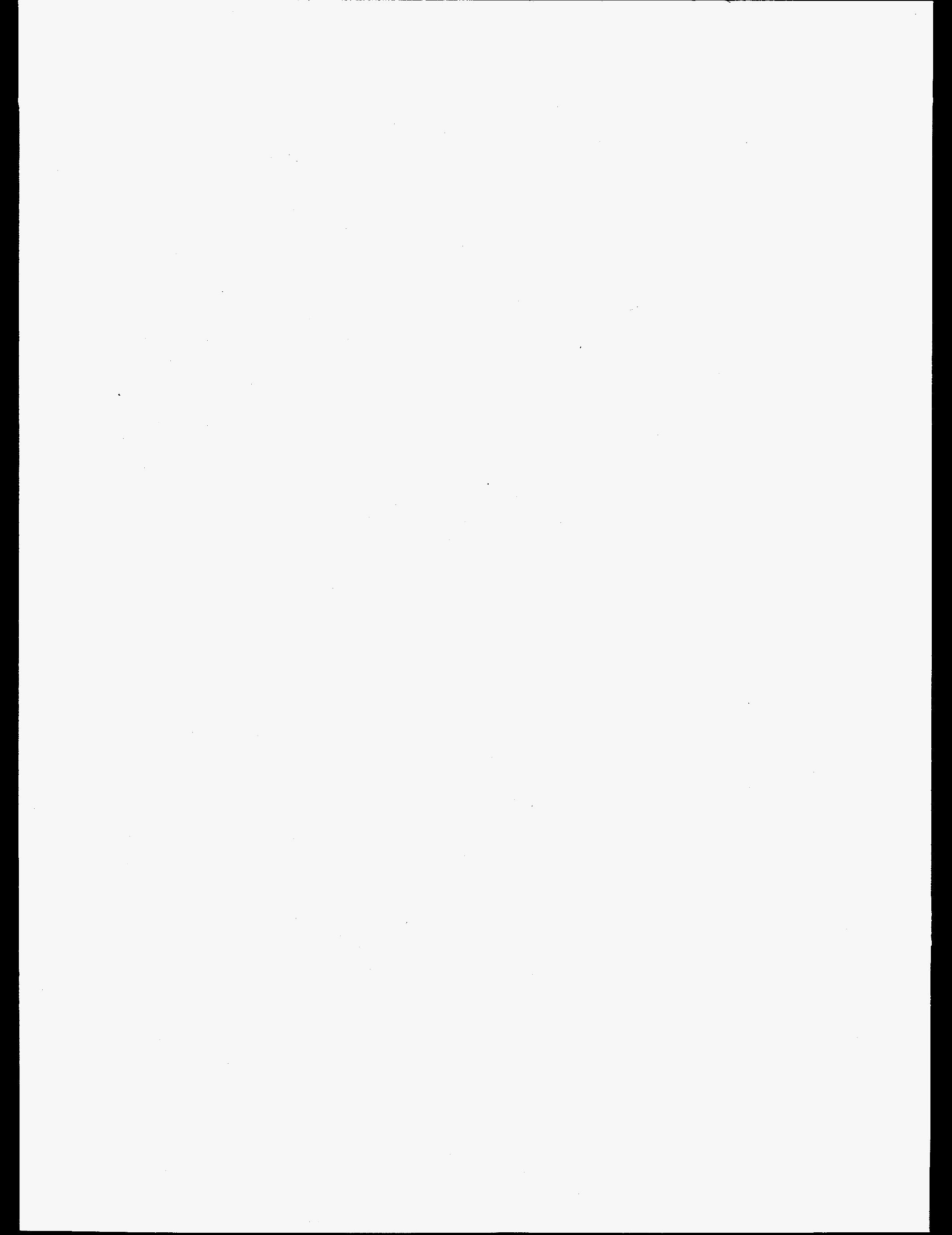




\section{CONTENTS}

1. Introduction $\ldots \ldots \ldots \ldots \ldots \ldots \ldots \ldots \ldots \ldots \ldots \ldots \ldots \ldots \ldots \ldots, 1$

2. Structural Requirements ..................... 3

3. Material Properties and Failure Criteria $\ldots \ldots \ldots \ldots \ldots \ldots \ldots$ 5

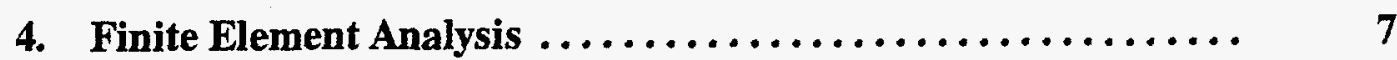

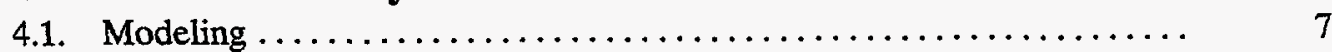

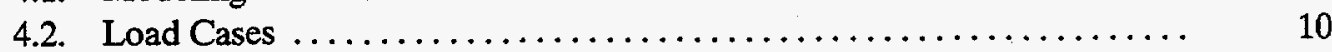

5. Dynamic Impact Simulation Results, Load Cases 1 - $3 \ldots \ldots \ldots$

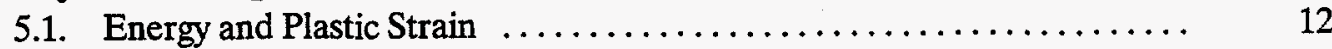

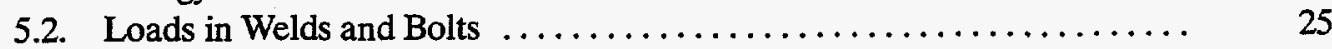

6. Static Analysis Results, Load Cases $4-5 \ldots \ldots \ldots \ldots \ldots \ldots \ldots$

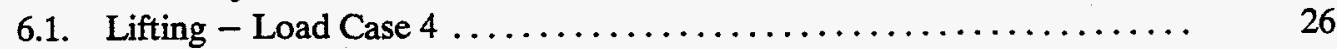

6.2. Stacking and Internal Pressure - Load Case $5 \ldots \ldots \ldots \ldots \ldots \ldots . \ldots . \ldots . \ldots 26$

7. Conclusions $\ldots \ldots \ldots \ldots \ldots \ldots \ldots \ldots \ldots \ldots \ldots \ldots \ldots \ldots \ldots, 30$

8. Acknowledgments $\ldots \ldots \ldots \ldots \ldots \ldots \ldots \ldots \ldots \ldots \ldots \ldots \ldots \ldots \ldots, 32$

9. References $\ldots \ldots \ldots \ldots \ldots \ldots \ldots \ldots \ldots \ldots \ldots \ldots \ldots \ldots \ldots \ldots, 33$

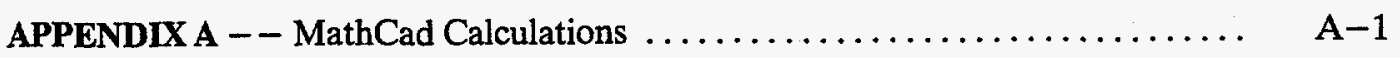

APPENDIX B - - Connection Load Diagrams ................. B -1

APPENDIX C - Computer Verification and Sample Data $\ldots \ldots \ldots \ldots \ldots \ldots \quad$ C-1 


\section{FIGURES}

Figure 1 Details of the 55 Gallon RSSC Design .............. 2

Figure 2 Portion of Finite Element Model Representing Steel ..... 8

Figure 3 Portion of Finite Element Model Representing Lead ...... 9

Figure 4 Contact Interactions and Bonds ................. 10

Figure 5 Plastic Strain in Stainless Steel for End Impact ......... 13

Figure 6 Plastic Strain in Lead for End Impact .............. 15

Figure 7 Plastic Strain in Stainless Steel for Side Impact . . . . . . . . 17

Figure 8 Plastic Strain in Lead for Side Impact . . . . . . . . . . . . . . 19

Figure 9 Plastic Strain in Stainless Steel for Corner Impact . . . . . . . 21

Figure 10 Plastic Strain in Lead for Corner Impact ............. 23

Figure 11 Von Mises Stress in Stainless Steel for Load Case 5 . . . . . . 28

Figure B-1 Connection Loads, End Impact, Bolts .......... B B-2

Figure B-2 Connection Loads, End Impact, Plate Welds ....... B B-2

Figure B-3 Connection Loads, End Impact, Bolt Ring Welds .... B-3

Figure B-4 Connection Loads, Side Impact, Bolts ........... B B

Figure B-5 Connection Loads, Side Impact, Plate Welds ........ B B-4

Figure B-6 Connection Loads, Side Impact, Bolt Ring Welds .... . B-4

Figure B-7 Connection Loads, Corner Impact, Bolts ......... B B-5

Figure B-8 Connection Loads, Corner Impact, Plate Welds ..... . B B-5

Figure B-9 Connection Loads, Corner Impact, Bolt Ring Welds ... B B-6 


\section{TABLES}

Table 1 Material Properties for RSSC - True Stress and True Strain 5

Table 2 Failure Criteria for Bolts and Major Welds ............ 6 Table 3 Load Cases for ABAQUS Analyses of 55 Gallon RSSC ....

Table 4 Maximum Equivalent Plastic Strains for Load Cases 1 - 3 .. 


\section{INTRODUCTION}

The INEL Recycled Shielded Storage Container (RSSC) is being developed primarily for the transportation and storage of mixed RH - TRU solid waste. The initial concept and design was funded under Lockheed Martin Idaho Technologies Company LDRD 2880. A 30 gallon version of the RSSC was analyzed for impact and structural loads in Ref. 1. This report primarily addresses the DOT 7A Type A structural requirements for the 55 gallon RSSC.

The container is designed to be constructed using contaminated lead and stainless steel potentially fulfilling two purposes; 1) waste transportation and storage, and 2) reducing the quantity of waste materials that require both storage and disposal. Currently, the INEL alone has approximately two million pounds of contaminated lead identified as a mixed waste. The funds set aside for storage and disposal of this material could potentially be used to construct the RSSC. This process, of course, will remove that lead (and any contaminated stainless steel used) from the mixed waste stockpile thus converting U.S. DOE liabilities into usable assets. Initially, four or five containers will be fabricated for demonstration, testing, and qualification to DOT 7A Type A requirements (Refs. 2 and 3 ) for radioactive solid waste shipping containers.

The RSSC will be made primarily of 304 stainless steel or equivalent (ASTM A-240 304 SST for plates). The internal voids will be filled with lead approximately 2.0 " to 2.625 " thick for shielding. The two lids are identical so that the container can be loaded from either end. The contents of the containers will consist of a standard 55 gallon drum filled with solid waste material of any particle size (U.S. DOT Forms 1-3). The contents have a maximum design weight of $1000 \mathrm{lbs}$. The 55 gallon version of the RSSC is not designed to have an internal liner or for liquid or gas contents. Details of the container are shown in Fig. 1.

The general requirements for the 55 gallon RSSC include:

(1) reduce radiation levels from $5 \mathrm{R} / \mathrm{hr}$ within the container to $200 \mathrm{mR} / \mathrm{hr}$ at the outside contact surfaces.

(2) accommodate a 55 gallon drum.

(3) be maneuverable with standard transport equipment.

(4) totally encapsulate the lead shielding.

(5) facilitate operational activities.

(6) be stackable.

(7) include ports for venting, sampling, and video access.

(8) minimize cost.

(9) meet DOT 7A Type A requirements for radioactive solid waste shipping containers. 

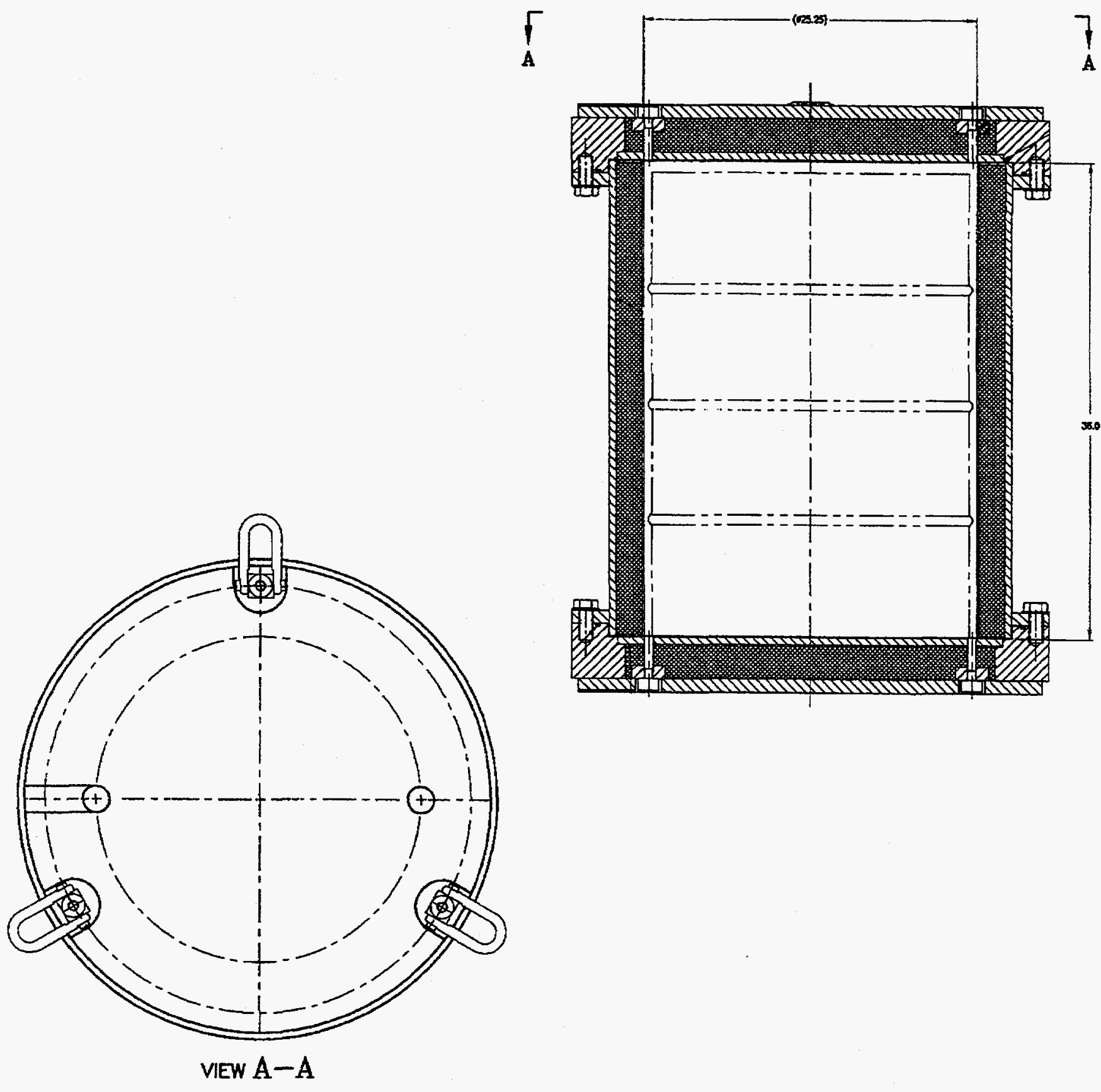

Figure 1. Details of the 55 Gallon RSSC Design (from Ref. 4) 


\section{STRUCTURAL REQUIREMENTS}

Dimensions and weights for the 55 gallon version of the RSSC are summarized below. The estimated weights were calculated using the I-DEAS solid model (Ref. 5, see also Section 4). Note that these values were multiplied by 2 since only $1 / 2$ of the container was actually modeled.

- Design weight of contents $=1000 \mathrm{lbs}$

- Estimated weight of loaded container $=7000 \mathrm{lbs}$

- Estimated weight of unloaded container $=6000 \mathrm{lbs}$

- Estimated weight of lead $=3750 \mathrm{lbs}$

- Estimated weight of stainless steel $=2250 \mathrm{lbs}$

- Estimated weight of each lid (end assembly) $=1375 \mathrm{lbs}$

- Estimated weight of body assembly $=3250 \mathrm{lbs}$

- Internal dimensions $=25.25$ " dia $\times 36.00$ " high

- External dimensions $=36.12 "$ dia $\times 44.25 "$ high

The primary structural requirement for the RSSC is that the contents must remain within the container and shielding must remain intact during and after a $4 \mathrm{ft}$ drop onto a rigid surface. The container is designed to prevent rupture of any of the external components but gross, potentially permanent deformation of the container as a result of the drop tests with minimal lead exposure is acceptable. The RSSC is also designed to totally encapsulate the lead shielding and to withstand stacking, internal pressure, lifting loads, tiedown failure, penetration, and a range of temperatures. Failure criteria for all structural load cases are addressed in Section 3.

The following DOT 7A Type A structural requirements (Refs. 2 and 3) are addressed by this report:

(1) Free fall drops a package up to $11,000 \mathrm{lbs}$ in total weight must withstand a $4 \mathrm{ft}$ drop onto a rigid surface in any orientation.

(2) Container stacking must withstand the stacking of five loaded containers on the top surface in addition to the dead weight of the container and contents.

(3) Internal pressure must withstand an internal pressure of 11.2 psi. (Note, the actual requirement is a reduction in ambient pressure to $3.6 \mathrm{psi}$ which is approximately equivalent to applying an internal pressure of $11.2 \mathrm{psi}$.) 
(4) Lifting attachments must withstand lifting loads with a factor of safety of 3 against yielding.

(5) Tiedown failure must withstand the failure of any tiedown attachment.

(6) Penetration must withstand a $3.3 \mathrm{ft}$ drop of a $13.2 \mathrm{lb}, 1.3^{\prime \prime}$ diameter steel rod

(7) Temperature must withstand a temperature range of -40 to $158 \mathrm{deg} F$.

Since the container has at least 2.0" of lead and 0.5 " of steel to prevent penetration, no analysis for the effect of the penetration test was considered necessary. Also, the material properties of both the steel and lead do not change significantly over the required temperature range. The RSSC is considered adequate to meet structural requirements 6 and 7 above without requiring further analyses.

4 


\section{MATERIAL PROPERTIES AND FAILURE CRITERIA}

For the impact load cases, permanent deformation of the various container components is acceptable if; 1 ) the contents are not released, and 2) shielding is not reduced. Maximum allowable plastic strain levels were determined in order to interpret the analysis results. Note that the American Society for Testing and Materials (ASTM, Ref. 6) generally specifies minimum yield and ultimate tensile stresses and elongation for 2 in. test specimens, but does not specify ultimate (rupture) strain levels.

Plastic properties are input to ABAQUS (Ref. 7, see also Section 4) in the form of stress - strain curves using true stress and true strain, which are related to the nominal or engineering stress and strain as follows:

$$
\begin{aligned}
& \sigma=\sigma_{\text {nom }}\left(1+\epsilon_{\text {nom }}\right) \\
& \epsilon=\ln \left(1+\epsilon_{\text {nom }}\right)
\end{aligned}
$$

The first of these equations assumes that there is no volumetric change in the material during plastic deformation. The steel and lead were modeled as elastic-perfectly plastic materials with the maximum stress set at the true yield stress. Strain levels were not allowed to exceed the true ultimate strain in the analysis. The properties used as input for ABAQUS are listed in Table 1 .

Table 1 .Material Properties for RSSC - True Stress and True Strain

\begin{tabular}{|c|c|c|c|c|c|c|}
\hline Material & $\begin{array}{c}\text { Modulus } \\
\text { E, } \\
\text { (ksi) }\end{array}$ & $\begin{array}{c}\text { Yield } \\
\text { Stress, } \\
\text { (psi) }\end{array}$ & $\begin{array}{c}\text { Maximum } \\
\text { Allowable } \\
\text { Strain, } \\
\%\end{array}$ & $\begin{array}{c}\text { Ultimate } \\
\text { Strain, } \\
\%\end{array}$ & $\begin{array}{c}\text { Poisson's } \\
\text { Ratio }\end{array}$ & $\begin{array}{c}\text { Density } \\
\left.\text { (Ibs/in }{ }^{3}\right)\end{array}$ \\
\hline $\begin{array}{c}\text { 304 Stainless } \\
\text { Steel }\end{array}$ & 28,300 & 30,000 & 23.0 & 33.6 & 0.29 & 0.283 \\
\hline Lead & 2,000 & 8,000 & 33.0 & - & 0.425 & 0.410 \\
\hline
\end{tabular}

The U.S. DOE Rocky Flats facility (Ref. 8) conducted tests to determine the formability of 304 stainless steel sheet concluding that 304 sheet ruptures at about $36 \%$ effective (equivalent) plastic strain in a worst case biaxial stress state. In uniaxial tension tests, the effective strain at rupture is much higher. The failure strain occurring in the worst case biaxial tension should be a reasonable lower bound for essentially all stress states occurring in the RSSC. The maximum effective plastic strain was taken as approximately $2 / 3$ of $36 \%$ or $23 \%$ for these analyses in order to assure a margin of safety.

The lead properties were taken from Ref. 9. The dynamic tensile strength of lead is not well known. Two load cases for the 30 gallon RSSC (Ref. 1) were analyzed for each 
impact orientation using lead strengths of 8000 psi and 4000 psi. Using 8000 psi should provide an upper bound on the forces developed throughout the model while using 4000 psi should maximize the displacements. Since the results of these two load cases for the $\mathbf{3 0}$ gallon RSSC were nearly identical, only 8000 psi lead strength was considered for the 55 gallon RSSC.

The failure criteria used for the lid bolts and the 1/2" welds attaching the rings and 1" plates are listed in Table 2. These values were calculated in Appendix A. The container welds were conservatively assumed to have the same elastic properties as the 304 stainless steel. Note that the failure criteria in Table 2 do not allow the bolt or weld material to yield. Considerable deformation can generally take place in these connections before failure actually occurs.

Table 2 .Failure Criteria for Bolts and Major Welds used in ABAQUS Explicit Analysis

\begin{tabular}{|c|c|c|c|}
\hline Connection & $\begin{array}{c}\text { Tensile } \\
\text { Strength, } \\
\text { lbf }\end{array}$ & $\begin{array}{c}\text { Shear } \\
\text { Strength, } \\
\text { lbf }\end{array}$ & $\begin{array}{c}\text { Bolt } \\
\text { Elongation, } \\
\text { in }\end{array}$ \\
\hline 1" A325 Bolt & 72,000 & 43,000 & 0.006 \\
\hline $\begin{array}{c}\text { 1/2" Weld, } \\
\text { (Strength is per node) }\end{array}$ & 21,250 & 21,250 & - \\
\hline
\end{tabular}

For load case 4 (container stacking, internal pressure, and dead weight), the stresses in the stainless steel, bolts, and welds must be below $1 / 3$ yield. This criteria will also be used for load case 5 (lifting plus dead weight). 


\section{FINITE ELEMENT ANALYSIS}

The 55 gallon RSSC was modeled using I-DEAS (Ref. 5) for solid modeling, finite element mesh generation, and applying loads and boundary conditions. The model was then converted to ABAQUS Explicit (Ref. 7) format for all analysis and post processing of analysis results. The capabilities of ABAQUS Explicit were needed to; 1) treat interactions within the container (sliding surfaces, friction, and contact between the various parts), 2) model weld and bolt yield strengths, 3) analyze the effects of dynamic impacts, and 4) model the inelastic properties of lead and stainless steel. Computer verification data for all software are included in Appendix C.

\subsection{Modeling}

A single model was developed to address all impact orientations and static load combinations. A half model was used since the container and all load cases have symmetry about a plane through the axis of the container. Symmetry boundary conditions were applied to nodes on this plane. Note that a quarter model is not symmetric for a comer impact. Nominal values for the dimensions were used throughout in creating the solid model. Some minor details such as the filter/plug arrangement in the lids, sheet metal welds, and rubber seals were ignored. A rigid surface was used to simulate the impact. The global coordinate system was rotated for the corner impact load case to facilitate the definition of the initial velocity and rigid impact surface. Details of the finite element model are shown in Figs. 2-4.

Two types of elements were used; 1) 8-node linear bricks (ABAQUS type C3D8R) used to represent solid lead or thick stainless steel, and 2) 4-node thin shells (ABAQUS type S4R) used to represent sheet stainless steel or thin plates. These elements, when well proportioned, generally allow for smooth convergence for large displacement solutions. Element density was increased in areas within the model where contact and/or high strains were expected. The elements representing stainless steel and lead are shown in Figs. 2 and 3 respectively. A total of 15121 elements were used.

The solid models were partitioned prior to meshing to segregate the regions with lead and steel. No slippage was allowed between the lead and the steel elements. Contact surfaces (see Fig. 4 ) were defined to represent the mating surfaces between the lids and the container body. These contact surfaces allow frictional sliding between the elements when they come in contact without penetration of the elements on one surface by those on the other. The surfaces as modeled were initially in contact. Where the stainless steel was modeled with thin shell elements, the contact surface was offset half the thickness of the shell. ABAQUS automatically accounts for this distance such that the surfaces have initial contact. A friction coefficient of 0.4 was used (stainless steel on stainless steel). The major welds attaching the 1" thick lid plates and bolt rings, and the 1 " diameter bolts were modeled using bonds with strengths specified in Table 2 between the nodes on one surface and the elements on the other (Fig. 4 ). 


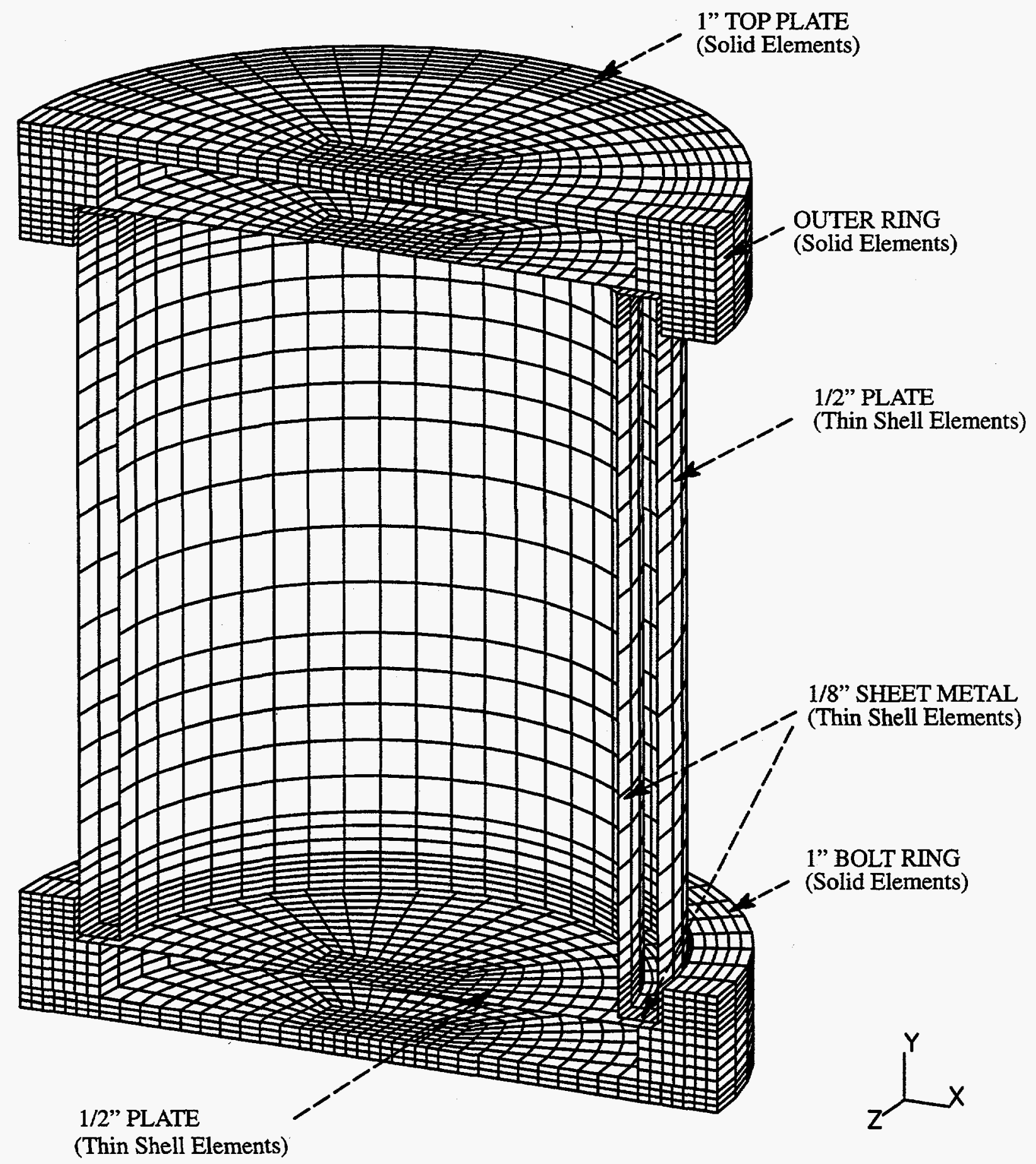

Figure 2. Portion of ABAQUS Finite Element Model Representing Steel 


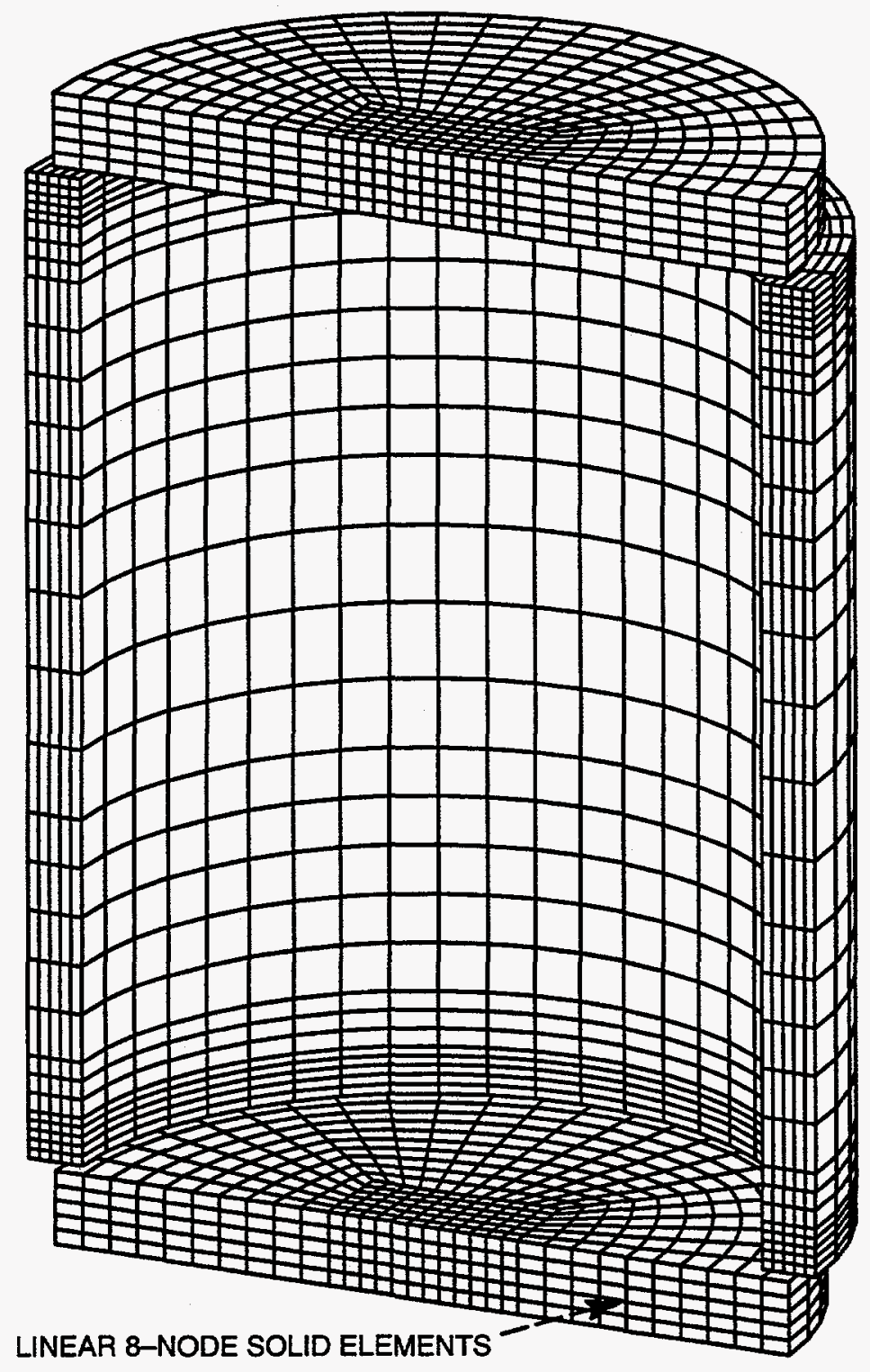<smiles>[Y]C([Z])[Y]</smiles>

Figure 3. Portion of ABAQUS Finite Element Model Representing Lead

9 


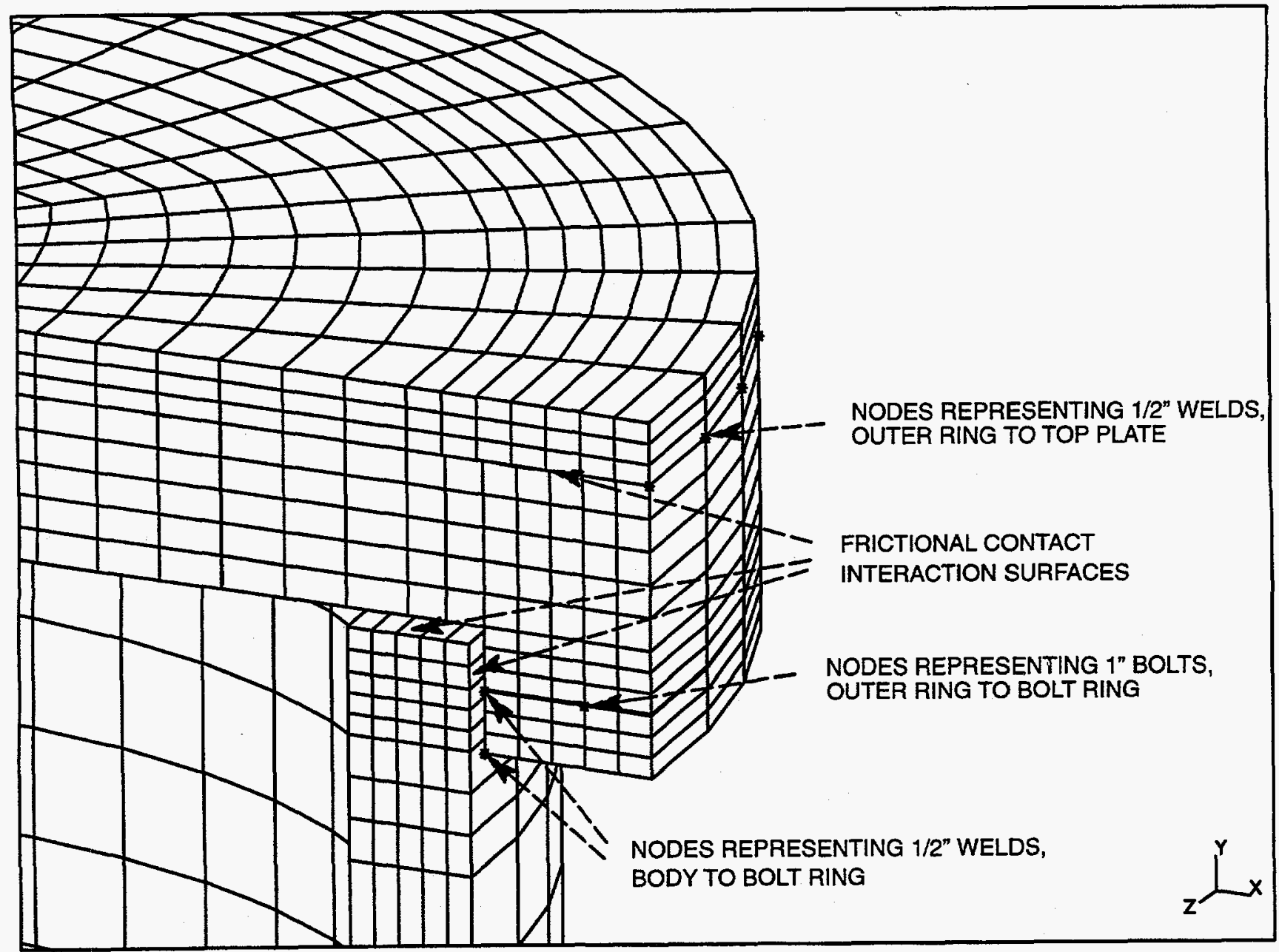

Figure 4. Contact Interactions and Bonds Between Nodes and Surfaces Used in ABAQUS Finite Element Model

\subsection{Load Cases}

Load cases used in the ABAQUS analyses are listed in Table 3 . For the impact load cases 1-3, the models were given an initial velocity of $193 \mathrm{in} / \mathrm{sec}$ (see Appendix A) toward the rigid surface and the weight of the contents was accounted for by increasing the density of shell elements near the impact but in the interior of the container.

The results from analysis of the 30 gallon RSSC in Ref. 1 (heavier than the 55 gallon version with identical lifting configuration) were used to address the lifting load case 4. For load case 5 , the weight of the contents was accounted for by increasing the density of the interior "floor" of the container. The stacking loads were simulated by applying a pressure to the top of the container of $37.5 \mathrm{psi}$ (see Appendix A) and restraining the container base plate. Internal pressure of $11.2 \mathrm{psi}$ was applied to the interior shell element faces. 
Table 3 .Load Cases for ABAQUS Analyses of 55 Gallon RSSC

\begin{tabular}{|c|l|}
\hline $\begin{array}{c}\text { LOAD } \\
\text { CASE }\end{array}$ & \multicolumn{1}{|c|}{ CONDITION } \\
\hline 1 & $4 f t$ Free Fall, End Impact \\
\hline 2 & $4 f t$ Free Fall, Side Impact \\
\hline 3 & $4 f t$ Free Fall, Corner Impact \\
\hline 4 & Lifting + Dead Weight \\
\hline 5 & Container Stacking + Dead Weight + Internal Pressure \\
\hline
\end{tabular}




\section{DYNAMIC IMPACT SIMULATION RESULTS, LOAD CASES 1-3}

Part of the testing done to qualify DOT 7A Type A containers involves dropping loaded, initially undamaged containers onto a rigid surface. Testing personnel generally choose 3 or 4 drop orientations judged to represent the worst cases for these tests.

Considerable damage to the tested container is acceptable but release of any contents or shielding reduction is not. In addition, the RSSC should be designed such that lead exposure during testing is minimal. Although the test containers are expected to be fabricated using clean lead, production containers may use contaminated lead and lead exposure at the container outside surfaces should be prevented.

Impacts were simulated for design purposes using ABAQUS Explicit (Ref. 7) and finite element models nearly identical to those used for the 30 gallon container (Ref. 1). All nodes in the model were given an initial velocity of $193 \mathrm{in} / \mathrm{sec}$ toward a rigid surface to represent a $4 \mathrm{ft}$ drop. End, side, and corner drop orientations were used. The orientation of the corner drop was adjusted so that the vertical direction passed through the center of gravity of the loaded container. The rigid surface was located initially at a distance of approximately 0.001 " from the container model and the effects of the impact were tracked for 0.006 to 0.01 seconds depending on the impact orientation. Results from these analyses include energy data, strain, stress, and forces in the connections as a function of time. In addition, displacements and velocities were monitored at specific locations within the container.

\subsection{Plastic Strain}

Plastic strain results from ABAQUS impact analyses are shown in Figs. 5 to 10 . Since the energy vers time and stress distribution versus time results are nearly identical to those for the $\mathbf{3 0}$ gallon RSSC, only the plastic strain results are presented here. Maximum strain levels are listed in Table 4 .

Table 4 .Maximum Equivalent Plastic Strains for Load Cases $1-3$

\begin{tabular}{|l|c|c|c|}
\hline \multicolumn{1}{|c|}{ Load Case } & $\begin{array}{c}\text { Maximum Strain in } \\
\text { Lead, \% }\end{array}$ & $\begin{array}{c}\text { Maximum Strain in } \\
\text { Steel, \% }\end{array}$ & $\begin{array}{c}\text { Strain in Steel, } \\
\text { Away from Impact } \\
\text { Corner, \% }\end{array}$ \\
\hline$\# 1$, End Impact & 1.07 & 4.42 & - \\
\hline$\# 2$, Side Impact & 1.77 & 4.64 & - \\
\hline$\# 3$, Corner Impact & 1.42 & $33.6^{*}$ & 3.22 \\
\hline
\end{tabular}

*Strains for some elements at the impact corner reached the ultimate strain level of $33.6 \%$. When this occurs, ABAQUS removes the stiffness of these elements from the model.

The strains for all dynamic load cases are well below the maximum acceptable levels of $23 \%$ for steel and $33 \%$ for lead except for the corner drops. For the corner impact load case, some steel elements in the impact corner reach the ultimate strain of $33.6 \%$ and these elements are removed from the analyses. Strains in the steel away from the impact corner, however, are less than $4 \%$. These strain levels are acceptable. 
Figure 5. Plastic Strain in Stainless Steel for End Impact, Displacement magnified by 10 


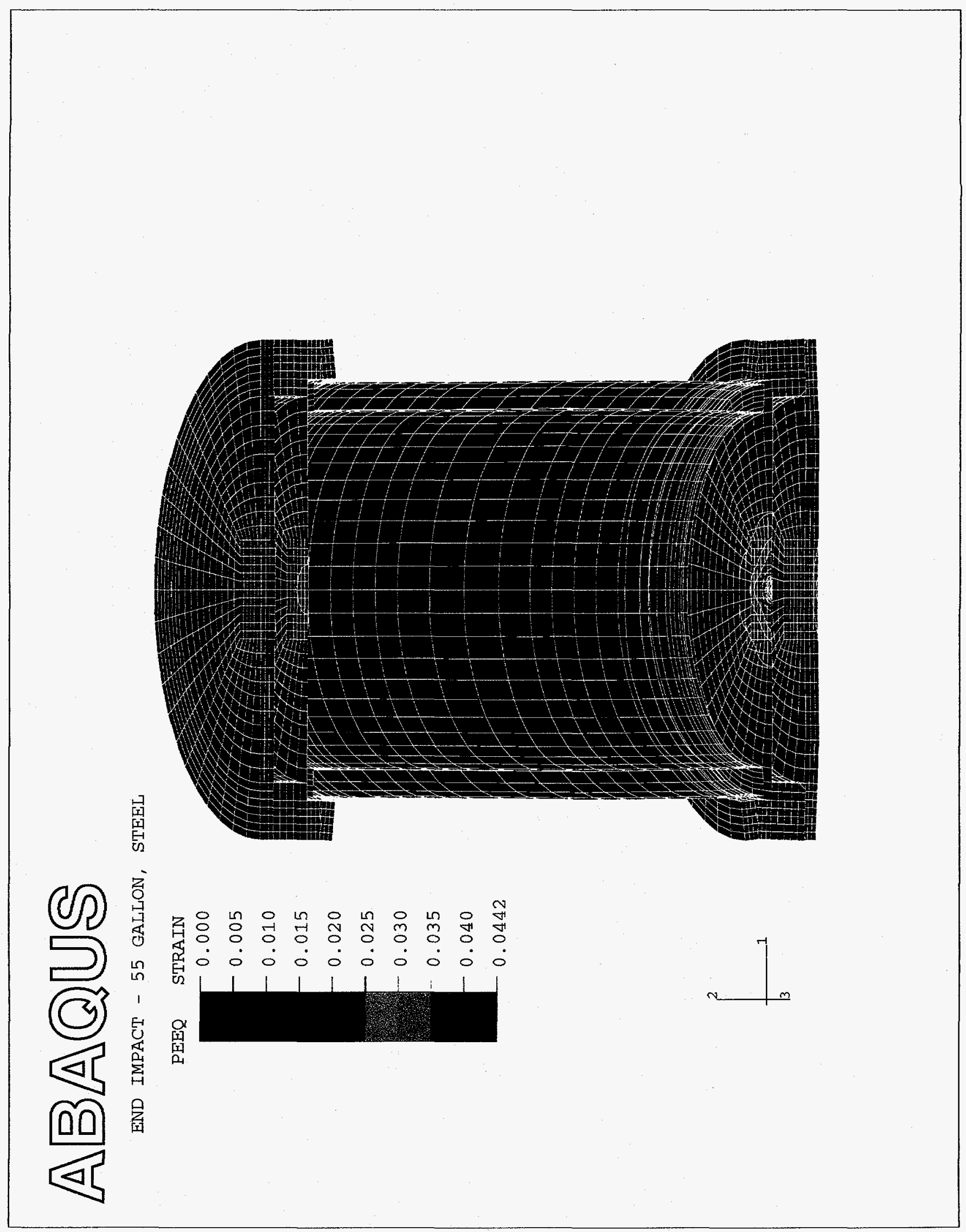


Figure 6. Plastic Strain in Lead for End Impact, Displacement magnified by 10 


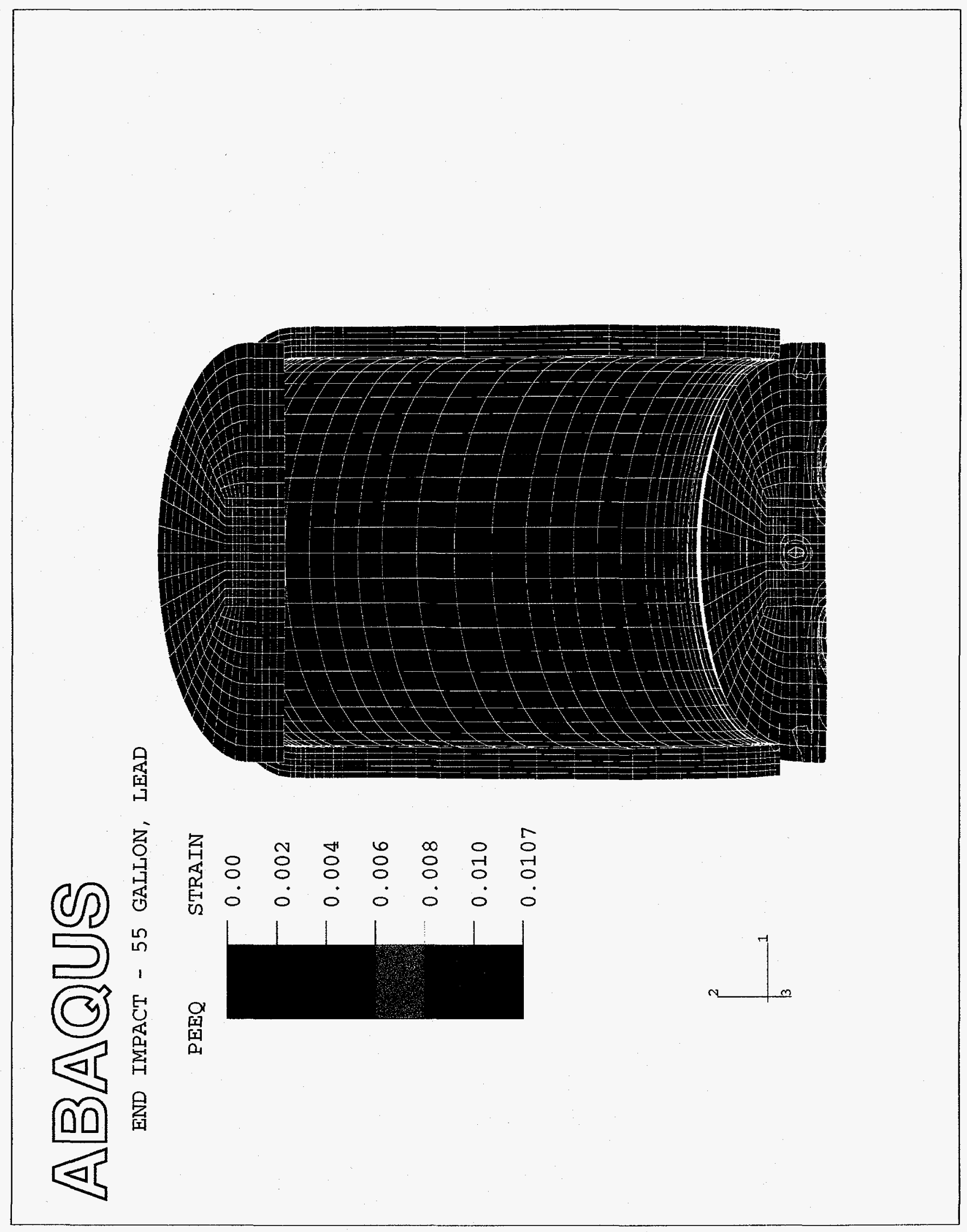


Figure 7. Plastic Strain in Stainless Steel for Side Impact, Displacement magnified by 10 


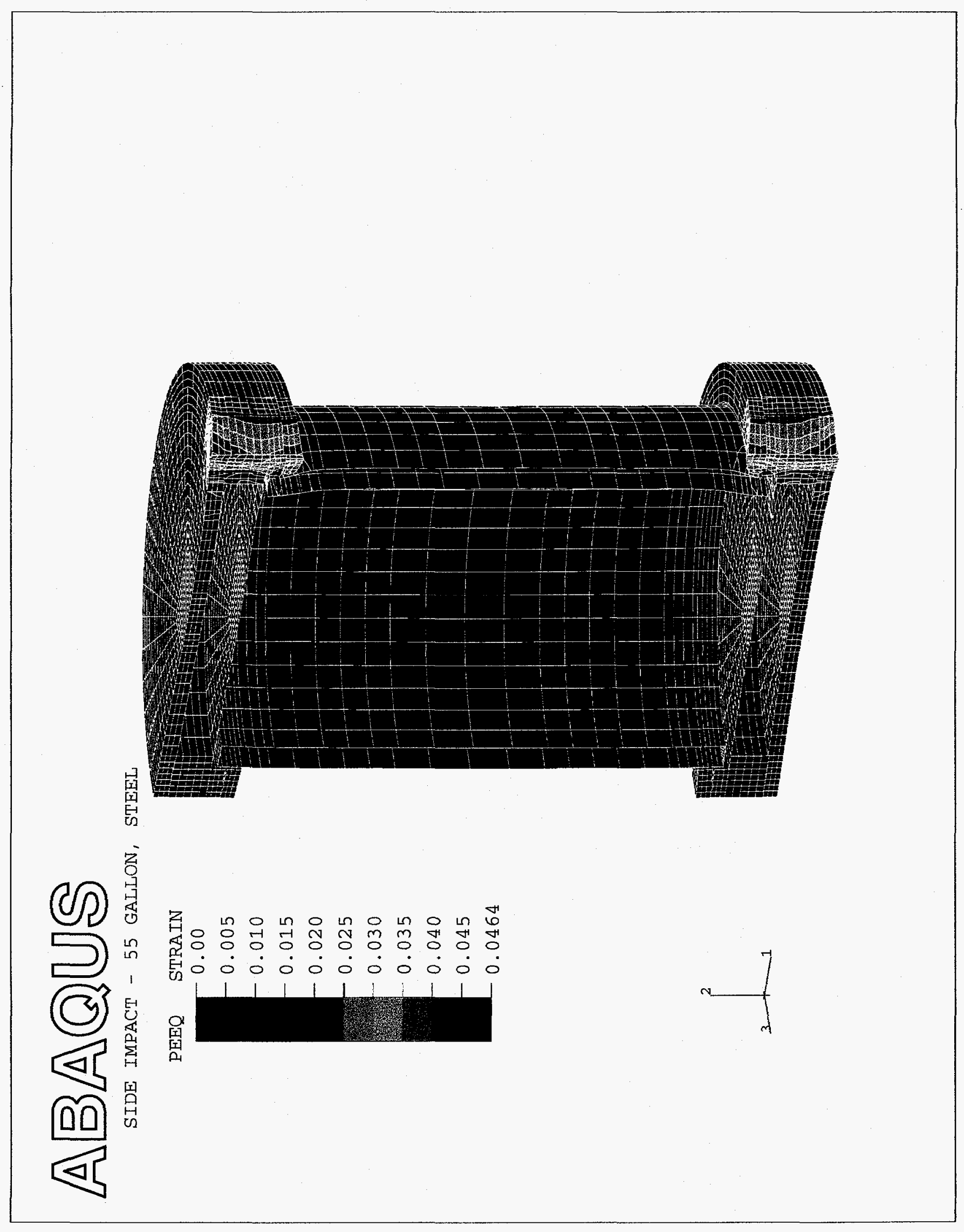


Figure 8. Plastic Strain in Lead for Side Impact, Displacement magnified by 10 


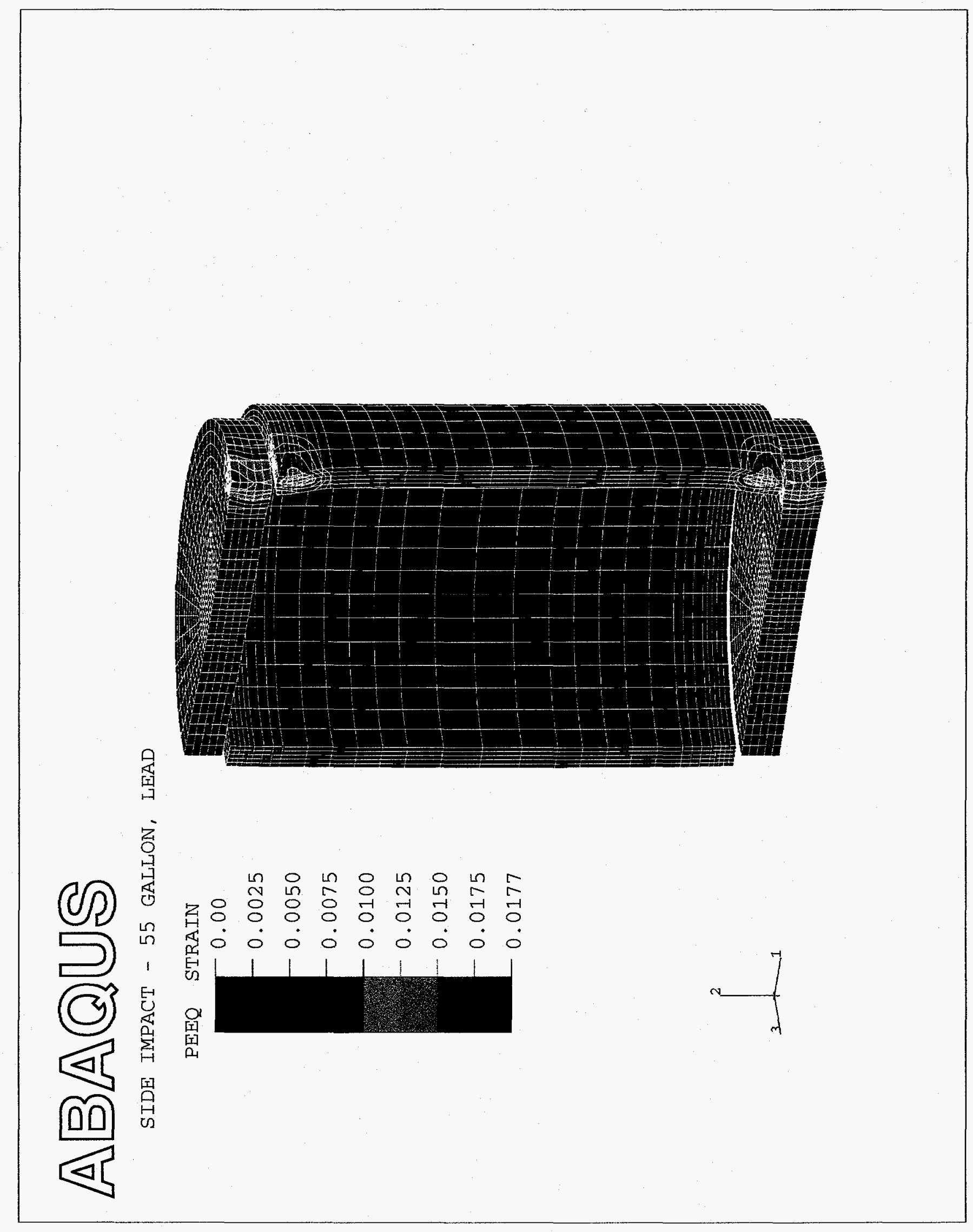


Figure 9. Plastic Strain in Stainless Steel for Corner Impact, Displacement shown to scale 


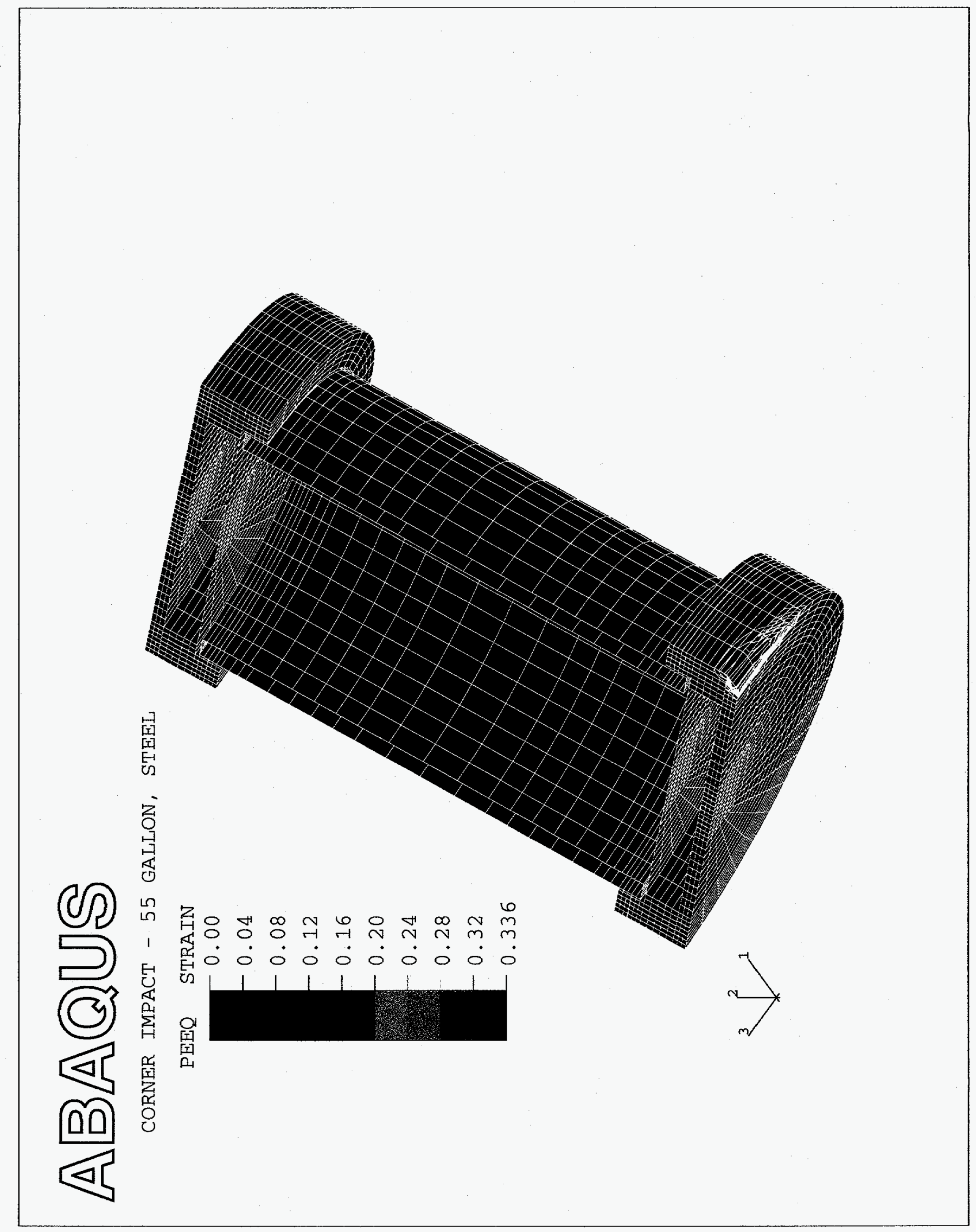


Figure 10. Plastic Strain in Lead for Corner Impact, Displacement shown to scale 


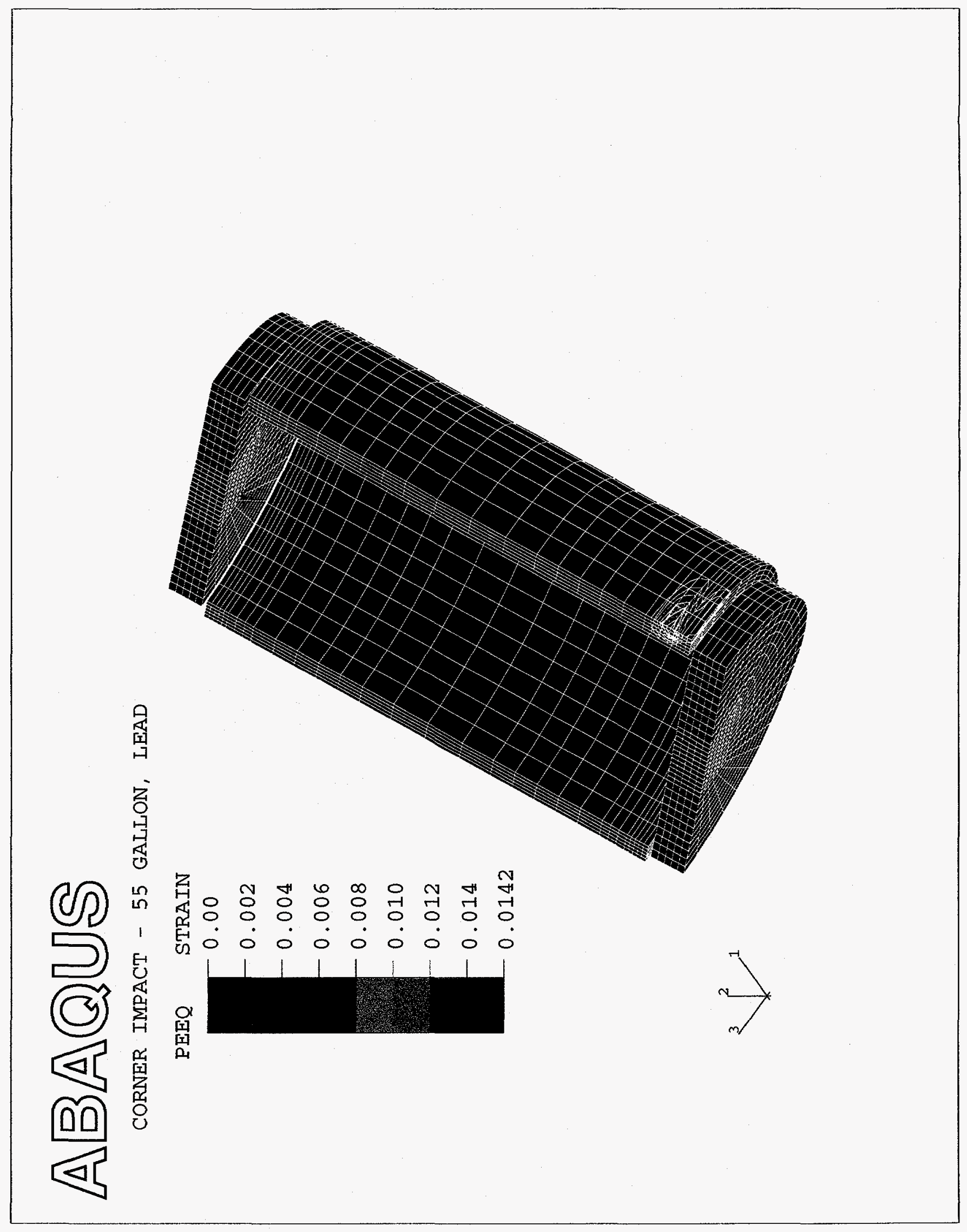




\subsection{Loads in Welds and Bolts}

The 1" diameter bolts and the major welds attaching the 1 "thick stainless steel lid plates and bolt rings were modeled using bonds between nodes on one surface and elements on the other. Although the welds are actually continuous around the container, the strengths of the welds were simulated in the finite element model as bonds at specific nodes. The tensile and shear forces in bolts and welds were limited to twice the forces predicted to cause yielding (see calculation of these forces in Appendix A). Yield forces in the bonds were reached, at least momentarily, on the load vers time diagrams shown in Figs. B-1 to B-9, Appendix $B$, when the load ratio reaches 0.5 . The analyses produced records of the maximum calculated forces and provided information used to design the bolts and welds.

The load ratios for the dynamic load cases remain below yield strengths for all bolts and welds with the following exceptions:

(1) In Fig. B-3, for the end impact (load case 1), welds at two node locations for the upper bolt ring are momentarily above yield and welds at two node locations for the lower bolt ring are momentarily at yield.

(2) In Fig. B-7, for the corner impact (load case 2), two bolts in the lower bolt ring are momentarily above yield.

(3) In Fig. B-9, for the corner impact (load case 3), welds at two node locations for the lower bolt ring are momentarily above yield.

In Ref. 1, a corner impact load case was analyzed where the bolts and welds were allowed to fail when yield was reached. The connections were then removed from the model for the remainder of the analysis with no bond strength assumed at the connection. All other connections remained intact without any continued failures.

The loads in the bolts and welds for the dynamic load cases for the 55 gallon RSSC remain at or below yield strengths during these impacts or are only momentarily slightly above yield. Since the dynamic strengths for the welds and bolts are probably above those predicted and yielding does not necessarily imply connection failure, these results are considered acceptable. 


\section{STATIC ANALYSIS RESULTS, LOAD CASES $4-5$}

\subsection{Lifting - Load Case 4}

\subsubsection{Swivel Hoist Rings and Threads in the Lid}

The RSSC is designed to be lifted using three swivel host rings (Crosby No. 1016935 or equivalent, Ref. 10) with working capacities of $5000 \mathrm{lbs}$ each. The ultimate capacity is 5 times the working capacity. The estimated weight (Appendix A) of the RSSC including contents is $7000 \mathrm{lbs}$. Although this is a three point lift, any two of the lifting points should be designed to handle the full weight together. Two of the swivel host rings can handle $10,000 \mathrm{lbs}$ with a factor of safety of 5 on ultimate strength. The threaded holes in the RSSC were evaluated in Appendix A and found to have sufficient thread engagement such that the full strength of the bolt (part of the host rings) can be developed. The three swivel hoist rings, therefore, have adequate capacity for lifting the RSSC.

Note that A574 bolts (Ref. 6) have minimum ultimate and yield strengths of 170 and $153 \mathrm{ksi}$, respectively. Although the DOT 7A Type A criteria require a factor of safety of 3 on yield strength for lifting attachments, in this case, a factor of safety of 5 on ultimate strength meets this intent.

\subsubsection{Container Stresses}

A gravity load was applied to the ABAQUS Explicit model of the 30 gallon RSSC in Ref. 1 to simulate load case 4 . Since the 30 gallon RSSC $(7300 \mathrm{lbs})$ is heavier that the 50 gallon RSSC (7000 lbs) evaluated here, using the results of the previous analysis is conservative. Note that the lids and lifting configurations are identical. Two nodes at the locations of the lifting ring threaded holes on the upper surface were restrained in translation in the vertical direction.

The maximum Von Mises stress in the steel was 2130 psi for this load case, well below the allowable stress of $1 / 3^{*}$ yield or 10,000 psi. Maximum stresses in the lead was about 100 psi. The loads in the bolts and welds were below $0.1^{*}$ yield. All stresses and connection loads for this load case were well below $1 / 3^{*}$ yield (or $1 / 5^{*}$ ultimate) and are acceptable.

\subsection{Stacking and Internal Pressure - Load Case 5}

Stacking, internal pressure, and dead weight (self weight) loads were applied simultaneously using the ABAQUS Explicit model. All nodes on the lower surface were restrained in translation in the vertical direction. An internal pressure of 11.2 psi was applied to the surfaces of the interior stainless steel shell elements. A pressure of 37.5 psi was applied to the upper surface on the container to simulate the stacking of five loaded containers. In addition, a gravity load was applied. 
The Von Mises stress distribution in the stainless steel for this load case is shown in Fig. 11. The maximum stress of 2020 psi is well below the allowable stress of $0.6^{*}$ yield or 18,000 psi. Maximum stresses in the lead for this load case are about $100 \mathrm{psi}$. The loads in the bolts and welds are below $0.1^{*}$ yield. All stresses and connection loads for this load case are well below $1 / 3^{*}$ yield (or $1 / 5^{\star}$ ultimate) and are acceptable. 
Figure 11. Von Mises Stress in Stainless Steel for Load Case 5 Stacking and Internal Pressure 


\section{ABA@US}

STATIC LOADS - 55 GALLON, STEEL

STACKING \& INTERNAL PRESSURE

MISES STRESS, PSI
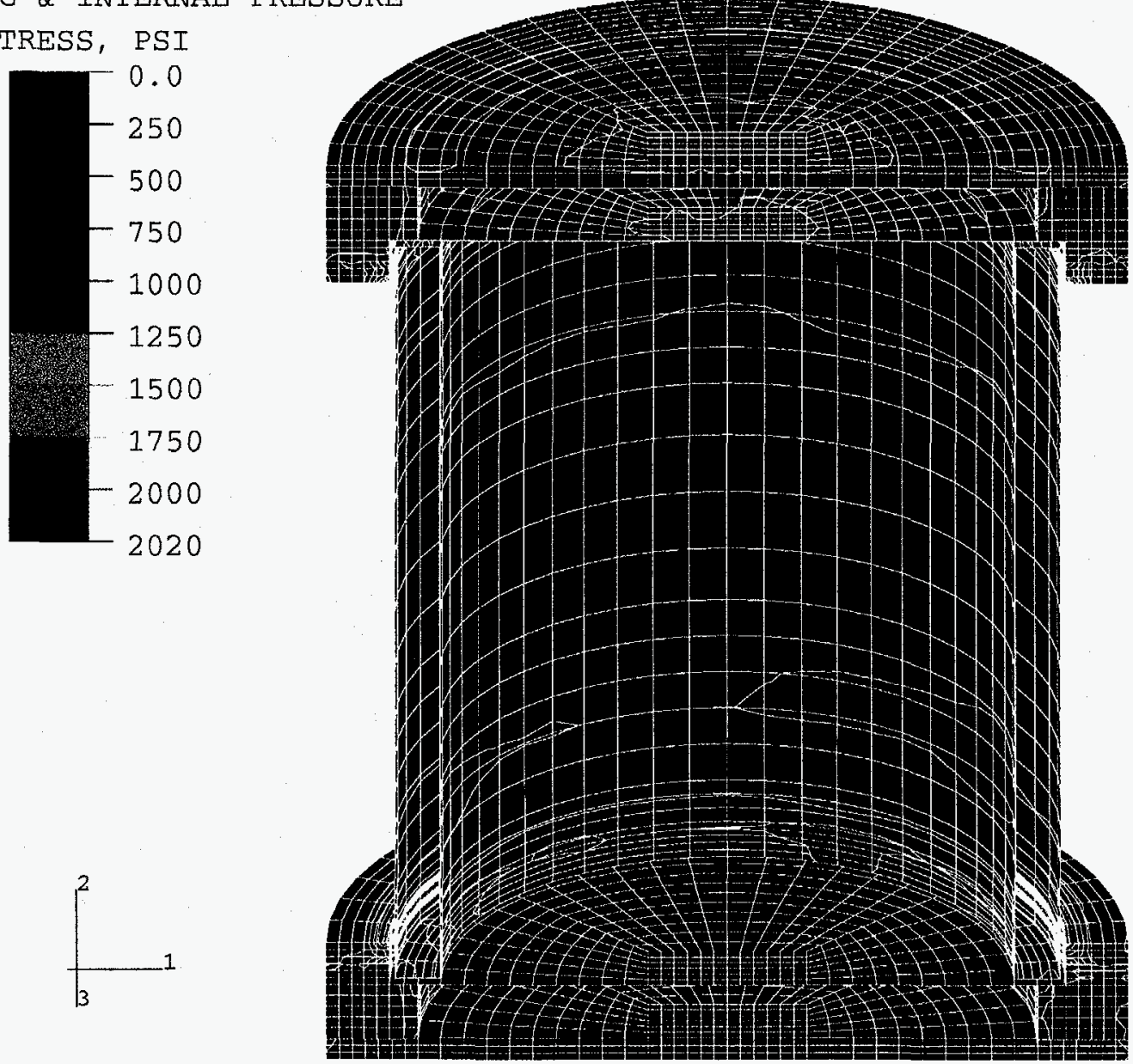


\section{CONCLUSIONS}

The analyses presented here support the conclusion that the 55 gallon version of the RSSC will meet DOT 7A Type A requirements for radioactive solid waste shipping containers. Note that the RSSC is not designed for liquid or gas contents. The controlling structural requirement is that the contents must remain within the container and shielding must remain intact during and after a $4 \mathrm{ft}$ drop onto a rigid surface. Lead exposure as a result of any package qualification testing or normal handling operations should be minimal. The container is designed to prevent rupture of any of the external components but gross, potentially permanent deformation of the container as a result of the drop tests is acceptable. In addition to the drop tests, the container must have a factor of safety of 3 against yielding during lifting and must withstand stacking and internal pressure loads.

The analysis results for the 55 gallon version of the RSSC are nearly identical to those for the $\mathbf{3 0}$ gallon version reported in Ref. 1 indicating that actual testing of both containers may not be necessary.

The following conclusions address the DOT 7A Type A structural requirements:

(1) Free fall drops $-4 \mathrm{ft}$ drops of loaded containers onto a rigid surface in any orientation may result in some damage in the stainless steel (corner drop) and yielding in the connections (end and comer drop) but the container is expected to pass these tests. The strain levels in the container outer steel surfaces are well below ultimate levels. Lead is not expected to be exposed during the impact tests or normal handling operations. The corner drop may result in yielding or failure of up to 3 bolts and/or yielding of short lengths of the welds attaching the bolt ring. This is not predicted to weaken the rest of the container. Also, the deformations in the container after a comer drop are small giving confidence that the remaining welds, bolts, rubber seal, and liner will continue to provide both containment and shielding.

(2) Container stacking - the stresses in the container and the loads in the connections are well below allowable levels when the RSSC is subjected to the stacking of five loaded containers on the top surface.

(3) Internal pressure - the stresses in the container and the loads in the connections are well below allowable levels when the RSSC is subjected to an internal pressure of $11.2 \mathrm{psi}$.

(4) Lifting - the RSSC and swivel hoist rings have factors of safety greater than 3 against yielding when lifting a loading container.

(5) Tiedown failure - the only tiedown attachments are the threaded holes in the lids. Failure of the threads in these holes will not reduce the integrity of the RSSC. 
(6) Penetration - the RSSC will withstand a $3.3 \mathrm{ft}$ drop of a $13.2 \mathrm{lb}, 1.3 \mathrm{\prime \prime}$ diameter steel rod.

(7) Temperature - the material properties do not vary significantly over a temperature range of -40 to 158 deg $F$.

The overall dimensions and weights for the 55 gallon RSSC are summarized below.

- Design weight of contents $=1000 \mathrm{lbs}$

- Estimated weight of loaded container $=7000 \mathrm{lbs}$

- Estimated weight of unloaded container $=6000 \mathrm{lbs}$

- Estimated weight of lead $=3750 \mathrm{lbs}$

- Estimated weight of stainless steel $=2250 \mathrm{lbs}$

- Estimated weight of each lid (end assembly) $=1375 \mathrm{lbs}$

- Estimated weight of body assembly $=3250 \mathrm{lbs}$

- Internal dimensions $=25.25$ " dia $\times 36.00$ " high

- External dimensions $=36.12$ " dia $\times 44.25^{\prime \prime}$ high 


\section{ACKNOWLEDGMENTS}

The initial concept and design was funded under Lockheed Martin Idaho Technologies LDRD 2880. The author would like to acknowledge the following Lockheed Martin Idaho Technologies personnel: T. E. Fewell and H. J. Welland for coordinating the project and design effort and R. L. Bratton for providing help with ABAQUS Explicit modeling. The report was reviewed for technical content by G. K. Miller of Lockheed Martin Idaho Technologies. 


\section{REFERENCES}

1 W. D. Richins, "Impact and Structural Analysis of the INEL 30 Gallon Recycled Shielded Storage Container," INEL-96-0141, Lockheed Idaho Technologies Company, May 1996.

2 U.S. Dept. of Transportation, 49 CFR Part 171 - 177, "Hazardous Materials, Transportation Regulations; Compatibility with Regulations of the International Atomic Energy Agency; Final Rule," Federal Register Vol. 60, No. 188, Sept. 28, 1995.

3 Regulator Compliance Guide for DOT-7A Type A Packaging Design, Rev. 1, Draft, WHC-SD-TP-RPT-017, Westinghouse Hanford Co. , received Dec. 1995.

4 Drawing 453291, "RWMC Mixed RH-TRU 55 Gallon Drum Shielded Container Suggested Configuration," Lockheed Idaho Technologies Co., 1996.

5 I-DEAS, Master Series 2.1, Structural Dynamics Research Corporation, Milford, OH,1995.

6 ASTM, "1993 Annual Book of ASTM Standards", American Society for Testing and Materials, 1993.

7 ABAQUS Explicit 5.4, Hibbitt, Karlsson, and Sorenson, Inc., Providence, Rhode Island, 1994.

8 G. J. Coubrough, D. K. Matlock, and C. J. VanTyne, "Formability of Type 304 Stainless Steel Sheet," Report No. RFP-4607, EG\&G - Rocky Flats Plant, December 1992.

9 Cask Designers Guide, L.B. Shappert, "A Guide for the Design, Fabrication, and Operation of Shipping Casks for Nuclear Application," ORNL-NSIC-68, Feb. 1970

10 Crosby Group Inc., General Catalog, 1992, Tulsa, OK.

11 MATHCAD, Version 3.1, DEC Platform, MathSoft Inc., 1993.

12 ASME/ANSI B1.1-1989, Unified Inch Screw Threads, American Society of Mechanical Engineers, 1989.

13 American Society of Mechanical Engineers, "ASME Boiler and Pressure Vessel Code," Section II, Part D, Materials, July 1, 1995 


\section{Appendix A}

\section{MATHCAD Calculations}

Appendix A includes MATHCAD (Ref. 11) calculations for the RSSC of:

1. impact velocity

2. estimated weight

3. equivalent stacking pressure

4. bolt failure criteria

5. weld failure criteria

6. required thread engagement for the swivel hoist rings 
CALCULATE THE IMPACT VELOCITY

$\begin{array}{ll}\mathrm{h}:=4 \cdot \mathrm{ft} & \text { Drop height per DOT 7A Type A Requirements } \\ \mathrm{g}:=386.4 \cdot \frac{\mathrm{in}}{\sec ^{2}} & \text { Acceleration of gravity } \\ \text { vel }:=(2 \cdot \mathrm{g} \cdot \mathrm{h})^{0.5} & \text { Impact velocity } \\ \text { vel }=192.6 \cdot \frac{\mathrm{in}}{\mathrm{sec}} & \end{array}$

Impact velocity used in ABAQUS Explicit analysis:

vel $:=193 \cdot \frac{\text { in }}{\mathrm{sec}}$ 
ESTIMATES OF WEIGHTS OF FULL CONTAINER BASED ON IDEAS MODEL

$$
\begin{array}{ll}
\mathrm{M}_{\mathrm{S}}:=2.868 \cdot \frac{\mathrm{lbf}}{\mathrm{in}} \cdot \mathrm{sec}^{2} & \text { Mass of steel from IDEAS half model } \\
\mathrm{M}_{\mathrm{L}}:=4.848 \cdot \frac{\mathrm{lbf}}{\mathrm{in}} \cdot \mathrm{sec}^{2} & \text { Mass of lead from IDEAS half model } \\
\mathrm{M}_{\mathrm{B}}:=1.294 \cdot \frac{\mathrm{lbf}}{\mathrm{in}} \cdot \sec ^{2} & \text { Mass of barrel for half model }(500 \mathrm{lbf}) \\
\mathrm{M}_{\mathrm{T}}:=\left(\mathrm{M}_{\mathrm{S}}+\mathrm{M}_{\mathrm{L}}+\mathrm{M}_{\mathrm{B}}\right) \cdot 2 & \text { Total mass of loaded container, full model } \\
\mathrm{W}_{\mathrm{T}}:=\mathrm{M}_{\mathrm{T}} \cdot 386.4 \cdot \frac{\mathrm{in}}{\mathrm{sec}^{2}} & \text { Total estimated weight of loaded container } \\
\mathrm{W}_{\mathrm{T}}=6963 \cdot 1 \mathrm{lbf} &
\end{array}
$$

Estimated weight of loaded container:

$$
\mathrm{W}_{\mathrm{T}}:=7000 \cdot \mathrm{lbf}
$$

Next, estimate the stacking pressure:

$$
\begin{array}{ll}
D_{\text {top }}:=35.25 \cdot \mathrm{in} & \text { Diameter of top (or bottom) lid } \\
A_{\text {top }}:=\pi \cdot\left(\frac{D_{\text {top }}}{2}\right)^{2} & \text { Area of top (or bottom) lid } \\
A_{\text {top }}=976 \cdot \text { in }^{2} & \text { Stacking pressure due to } 5 \text { loaded containers } \\
S_{\text {stack }}:=5 \cdot \frac{W_{T}}{A_{\text {top }}} & \\
S_{\text {stack }}=35.86 \cdot \text { psi } &
\end{array}
$$

Stacking pressure used in ABAQUS Explicit analysis:

$$
S_{\text {stack }}:=37.5 \cdot \mathrm{psi}
$$


BOLT STRENGTH - ESTIMATE THE YIELD CRITERIA FOR THE UD ATTACHMENT BOLTS USED IN THE ABAQUS EXPUCIT ANALYSIS

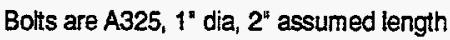

Material and dimensional data are from AISC ASD 9th ED unless othenwise noted

$$
\begin{aligned}
& \mathrm{L}_{\mathrm{b}}:=2 \cdot \mathrm{in} \\
& \mathrm{E}:=30 \cdot 10^{6} \cdot \mathrm{psi} \\
& \text { Area }:=0.7854 \cdot \mathrm{in}^{2} \\
& \mathrm{~F}_{\mathrm{yt}}:=92000 \cdot \mathrm{psi} \\
& \mathrm{F}_{\mathrm{ys}}:=0.6 \cdot \mathrm{F}_{\mathrm{yt}} \\
& \mathrm{F}_{\mathrm{ys}}=55200 \cdot \mathrm{psi} \\
& \mathrm{S}_{\mathrm{t}}:=\frac{\mathrm{F}_{\mathrm{yt}}}{\mathrm{E}} \\
& \mathrm{S}_{\mathrm{t}}=0.003 \cdot \frac{\mathrm{in}}{\mathrm{in}} \\
& \Delta:=\mathrm{L}_{\mathrm{b}} \cdot \mathrm{S}_{\mathrm{t}} \\
& \Delta=0.006 \cdot \mathrm{in}
\end{aligned}
$$

Assumed bolt length of 2 in for elongation limit

$$
\text { Modulus of elasticity }
$$

Tensile or shear area

Tensile yield stress

Estimate of shear yield stress, unpublished nuclear industry standard practice

Tensile yield strain

Bolt elongation at yield based on an assumed initial bolt length of $2^{\prime \prime}$.

Failure criteria for bolts:

$$
\begin{array}{ll}
F_{t}:=F_{y t} \cdot \text { Area } & \text { Yield tensile strength of each bolt } \\
F_{t}=72257 \cdot \mathrm{lbf} & \\
F_{S}:=F_{y s} \cdot \text { Area } & \text { Yield shear strength of each bolt } \\
F_{S}=43354 \cdot 1 \mathrm{bf} & \\
\Delta=0.006 \cdot \mathrm{in} & \text { Elongation of each bolt at yield }
\end{array}
$$
$\Delta=0.006 \cdot$ in

\section{Elongation of each bolt at yield}

Failure criteria for bolts used in ABAQUS Explicit models:

$$
\begin{aligned}
& F_{t}:=72000 \cdot \mathrm{lbs} \\
& F_{S}:=43000 \cdot \mathrm{lbf} \\
& \Delta=0.006 * \text { in }
\end{aligned}
$$


WELD STRENGTH - ESTIMATE THE YIELD CRITERIA FOR THE WELDS USED IN THE ABAQUS EXPLICIT ANALYSIS

All welds are 1/2" fillets or equivalent, around the circumference of the container. The following estimates the yield strength per node for each weld represented in the ABAQUS Explicit models.
dia $:=30.625 \cdot$ in
Diameter of container
$L_{W}:=\pi \cdot d i a$
Length of weld
$L_{\mathrm{w}}=96 \cdot \mathrm{in}$
$w_{\text {size }}:=0.5 \cdot$ in
Nominal weld size
$t_{e}:=0.707 \cdot w_{\text {size }}$
Effective throat thickness
$t_{e}=0.353 \cdot$ in
$F_{y w}:=30000 \cdot p s i$
Estimate of weld yield stress based on actual (not minimum) yield stress for 304L stainless steel base material$$
F_{w}:=t_{e} \cdot L_{w} \cdot F_{y w}
$$
Yield strength of entire circumferential weld
$F_{W}=1020321 \cdot \mathrm{lbf}$$$
\text { nodes }:=24
$$
Number of nodes representing the weld in the half model

$$
\mathrm{S}_{\mathrm{W}}:=\frac{\mathrm{F}_{\mathrm{w}}}{2 \cdot \text { nodes }}
$$
Yield strength of the weld at each node, reduced by $1 / 2$ since only haff of the container is modeled.

$$
S_{W}=21257 \cdot 16 f
$$

Failure criteria for welds used in ABAQUS Explicit models:
$S_{\mathrm{w}}:=21250 \cdot \mathrm{lbf}$
Weld yield strength at each node used in the ABAQUS Explicit models.




\section{CHECK THE THREAD ENGAGEMENT FOR THE SWIVLL HOIST RINGS}

The swivel hoist rings are Crosby No. 1016935 or equivalent with a rated working load limit of $5000 \mathrm{lbf}$ each. The working load is $1 / 5$ of the ultimate load. The bolts are Grade 8 ASTM A574, UNC-3A, $3 / 4^{\prime \prime}-10 \times 2.75^{\prime \prime}$. The threaded holes are UNC-2B, $3 / 4^{\prime \prime}-10$ and pass through a $1 / 2^{\prime \prime}$ section of plate and then $1.25^{\prime \prime}$ into the outer ring. They have at least 1 " of thread engagement.

$$
\begin{aligned}
& \mathrm{n}:=\frac{10}{\text { in }} \quad n=\text { threads per inch. } \\
& D:=\frac{3}{4} \cdot \text { in } \quad D=\text { nominal screw dia } \\
& A_{S}:=0.7854 \cdot\left(D-\frac{0.9743}{n}\right)^{2} \quad \begin{array}{l}
A_{S}=\text { tensile stress area per ANS| } B 1.1, \\
1974, \text { para } C .2
\end{array} \\
& A_{S}=0.334 \cdot i^{2} \\
& S_{\mathrm{St}}:=170000 \cdot \mathrm{psi} \quad S_{\mathrm{St}}=\text { ultimate tensile stress of external thread material, } A 574 \\
& S_{n t}:=75000 \cdot p s i \quad S_{n S}=\text { ultimate tensile stress of intemal thread material, } 304 \text { SS }
\end{aligned}
$$

Can the joint develop the full capacity of the bolt? Per ANSI B1.1-1974, Para. C.5, the minimum thread engagement to develop full strength is $L E_{\min }$

Ds a min major dia of external threads En $=$ max pitch dia of internal thread

$$
D_{s}:=0.7371 \cdot \text { in } \quad E_{n}:=0.6927 \cdot \text { in }
$$$$
L_{\min }:=\frac{S_{s t} \cdot 2 \cdot A_{s}}{S_{n t} \cdot \pi \cdot n \cdot D_{s} \cdot\left[\frac{1}{2 \cdot n}+\left|0.57735 \cdot\left(D_{s}-E_{n}\right)\right|\right]}
$$

$\mathrm{LE}_{\min }=0.87 \cdot \mathrm{in}$

$$
L E_{a}:=1.00 \cdot \text { in } \quad L E_{a}=\text { minimum actual length of thread engagement. }
$$

Since the actual thread engagement exceeds the minimum required, the internal threads can develop the full strength of the boit. 


\section{Appendix B}

\section{Connection Load Diagrams}

Appendix $B$ contains time vers load in connection diagrams for all dynamic impact load cases. A load ratio of 0.5 indicates that the load in the connection has reached the yield load identified in Table 2 . Diagrams are included for the major connections in the RSSC; 1) the bolts connecting the lids to the container body, 2) the plate welds that connect the 1" steel plates to the outer rings, and 3 ) the welds connecting the 1 " steel bolt rings to the $1 / 2$ " steel plate on the container body. 


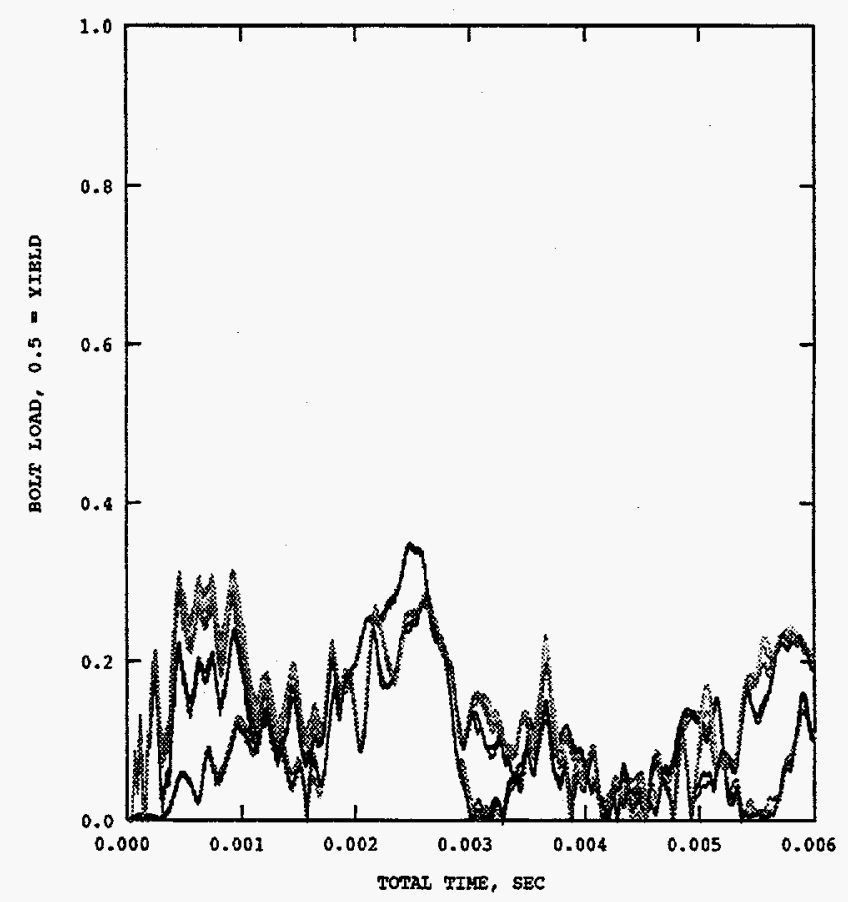

Figure B-1 . Connection Loads, End Impact, Bolts

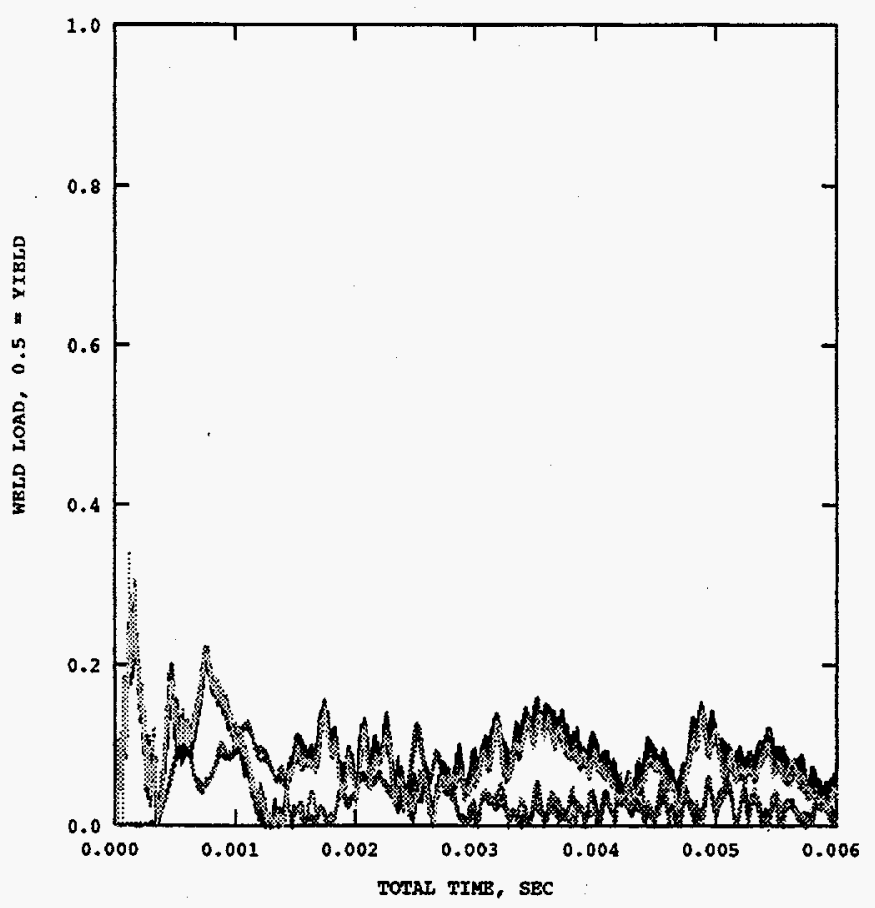

Figure B-2 . Connection Loads, End Impact, Plate Welds 


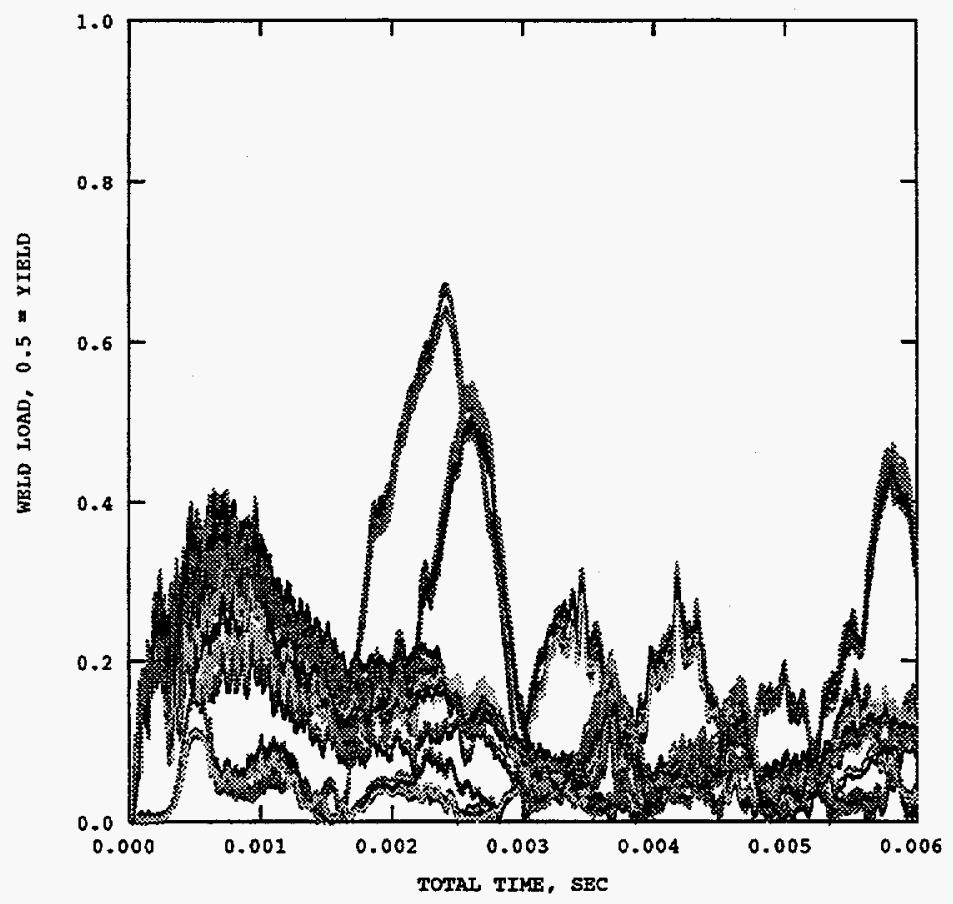

Figure B-3 . Connection Loads, End Impact, Bolt Ring Welds

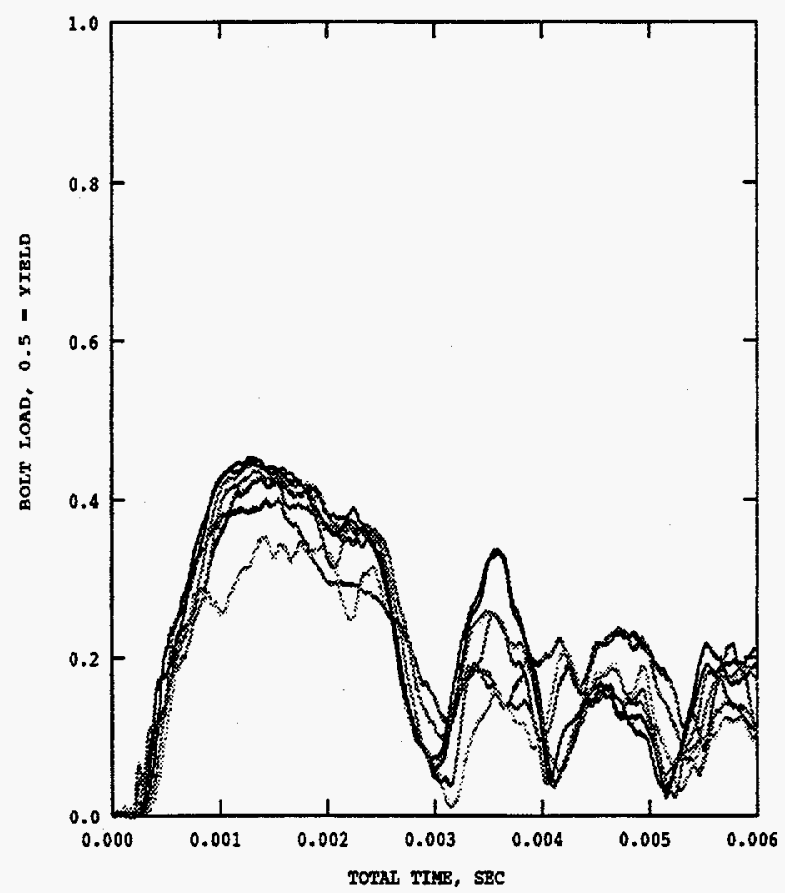

Figure B-4 . Connection Loads, Side Impact, Bolts 


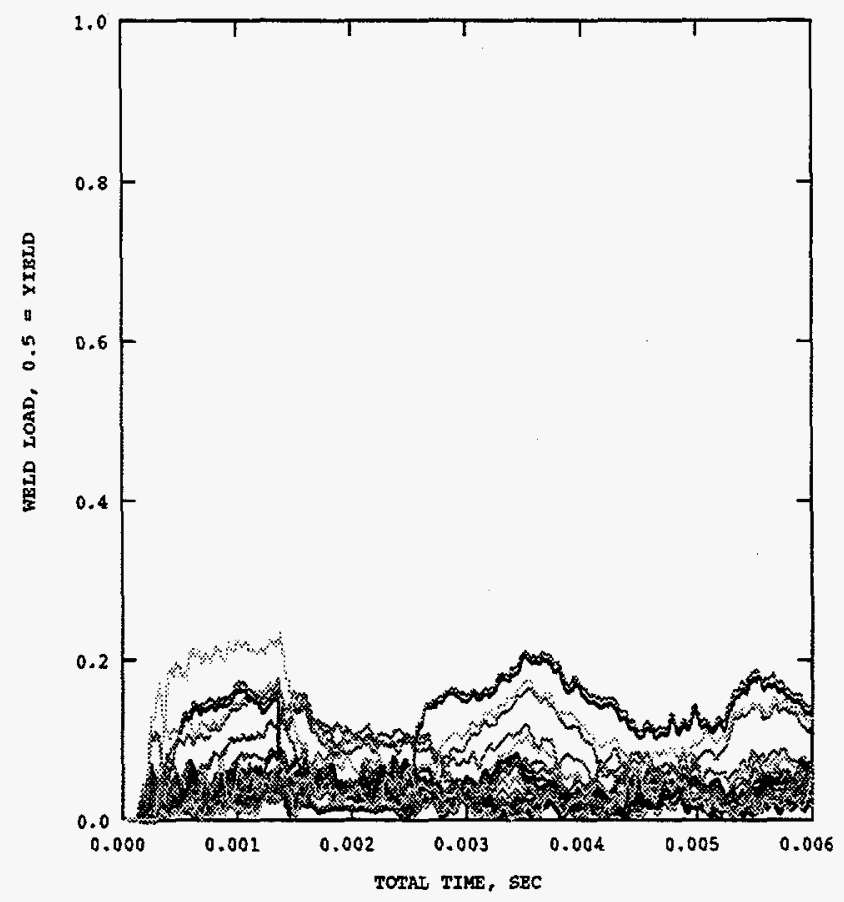

Figure B-5 . Connection Loads, Side Impact, Plate Welds

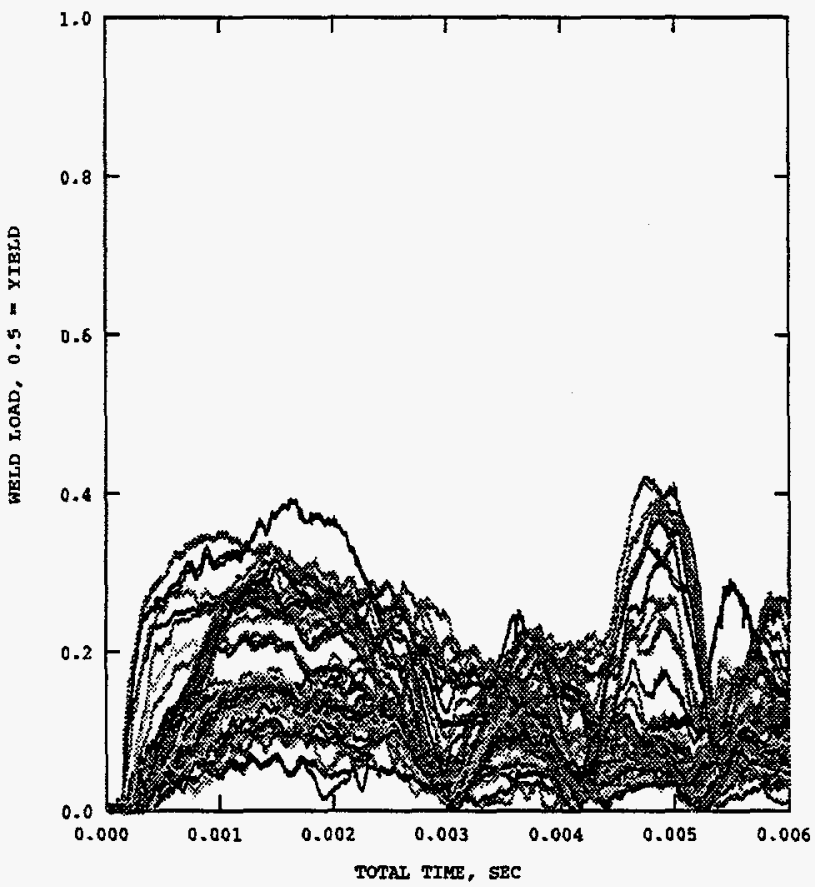

Figure B-6 . Connection Loads, Side Impact, Bolt Ring Welds 


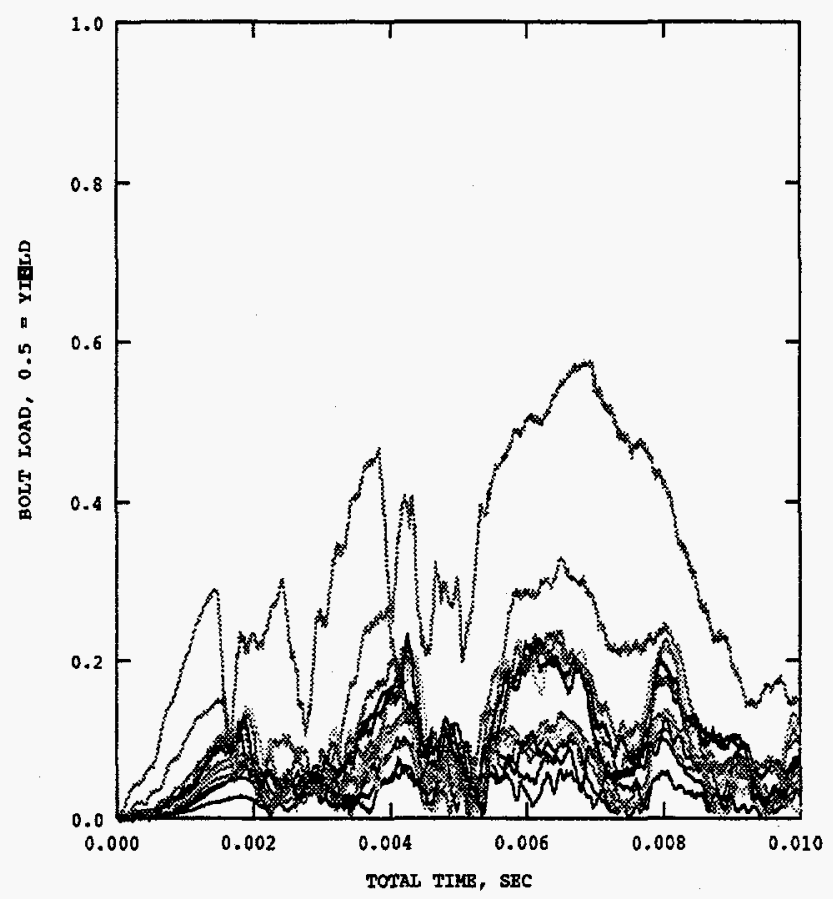

Figure B-7 . Connection Loads, Corner Impact, Bolts

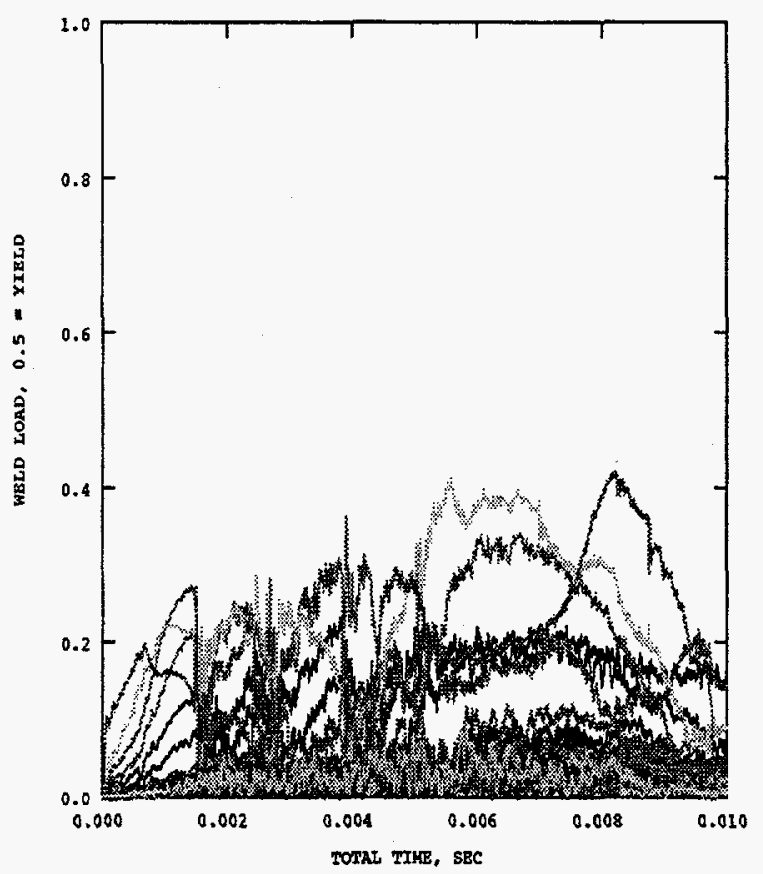

Figure B-8 . Connection Loads, Corner Impact, Plate Welds 


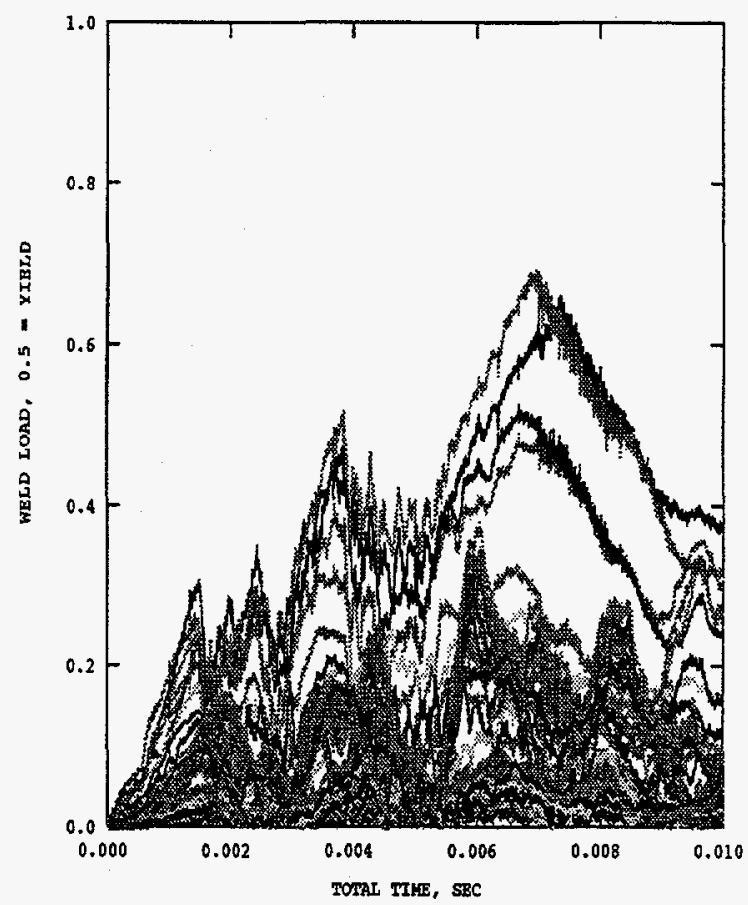

Figure B-9. Connection Loads, Corner Impact, Bolt Ring Welds 


\section{Appendix C}

\section{Computer Verification and Sample Data}

Appendix $C$ includes:

1. Documentation of computer configuration and verification

2. Sample Listing of ABAQUS Explicit finite element input data 


\section{COMPUTER CONFIGURATION AND VERIFICATION}

The following documentation presents the traceability for computer programs used in the analysis reported here.

Report Title: Impact and Structural Analysis of the INEL 55 Gallon Recycled Shielded Container

Author: W. D. Richins

Date: July 1996

Program Used: $\quad$ I-DEAS Version: Master Series 2.1

Computer Used: $\quad$ DEC ALPHA Station ASHTON

Verification Manual/Test Problem Manual/Example Manual:

-SDRC I-DEAS Verification Manual, Structural Dynamics Research Corporation, Milford, $\mathrm{OH}$

C. C. O'Brien letter to Applied Mechanics, Jan. 24, 1995, "Verification of SDRC I-DEAS MS 1.3C Software for the DEC Platform," CCO-03-95.

Program Used: $\quad$ ABAQUS Explicit Version: 5.4

Computer Used: $\quad$ DEC ALPHA Stations ASHTON and DURANGO

Verification Manual/Test Problem Manual/Example Manual:

ABAQUS Example Problems Manual, Hibbitt, Karlsson, and Sorenson, Inc.,

Providence, Rhode Island, 1994.

C. C. O'Brien letter to Applied Mechanics, February 7, 1995, "Verification of HKS ABAQUS Version 5.4 for the DEC Alpha Platform," CCO-04-95.

Program Used: MathCad

Version: 4.0

Module: NA

Computer Used: DEC5000 Model: $5000 / 200$

Verification Manual/Test Problem Manual/Example Manual: None

Author: NA

Date: NA

Comments: Application validated by hand calculation during check. 


\section{SAMPLE INPUT FILES FOR ABAQUS EXPLICIT ANALYSIS}


The following lists sample input data for ABAQUS Explicit used in this report. The node coordinates, element definitions, and set definitions have been removed due to the volume.

\section{INPUT DATA FOR SIDE IMPACT}

*HEADING

SIDE DROP OF 55 GALLON MODEL

**

**SDRC I-DEAS ABAQUS FILE TRANSLATOR 09-Jul-96 07:38:29

**

*PREPRINT, ECHO=NO, HISTORY=YES

*****

*NODE, SYSTEM $=\mathrm{R}$

*ELEMENT,TYPE $=S 4 \mathrm{R} \quad$,ELSET $=\mathrm{E} 0000001$

*ELEMENT,TYPE $=S 4 R$,ELSET=E0000002

*ELEMENT,TYPE=S4R ,ELSET=E0000003

*ELEMENT,TYPE=R3D4 ,ELSET=RIGID

*ELEMENT,TYPE $=$ C3D8R, ELSET $=E 0000005$

*ELEMENT,TYPE=C3D8R ,ELSET=E0000006

**

** MATERIAL DEFINITIONS, ETC ****

$* *$

*RIGID BODY,ELSET=RIGID,REF NODE= 20004

**

*SHELL SECTION,ELSET=E0000001,MATERIAL=STEEL

$5.000 \mathrm{E}-013$

*SHELL SECTION,ELSET=E0000002,MATERIAL=STEEL

1.250E-01 3

*SHELL SECTION,ELSET=E0000003,MATERIAL=STEELHVY

$1.250 \mathrm{E}-01 \quad 3$

*SOLID SECTION,ELSET=E0000005,MATERIAL=STEEL

*SOLID SECTION,ELSET=E0000006,MATERIAL=LEAD

**

$* *$

$* *$

*MATERIAL,NAME=STEEL

*ELASTIC,TYPE=ISOTROPIC

2.83E+07, 0.29

*DENSITY

7.324E-04

*PLASTIC

30000.0 .

***

*MATERIAL,NAME=STEELHVY

*ELASTIC,TYPE=ISOTROPIC

$2.83 \mathrm{E}+07,0.29$

*DENSITY

3.560E-02

*PLASTIC

$30000 ., 0$.

**

*MATERIAL,NAME=LEAD

*ELASTIC,TYPE=ISOTROPIC

$2.0 \mathrm{E}+06, .425$ 


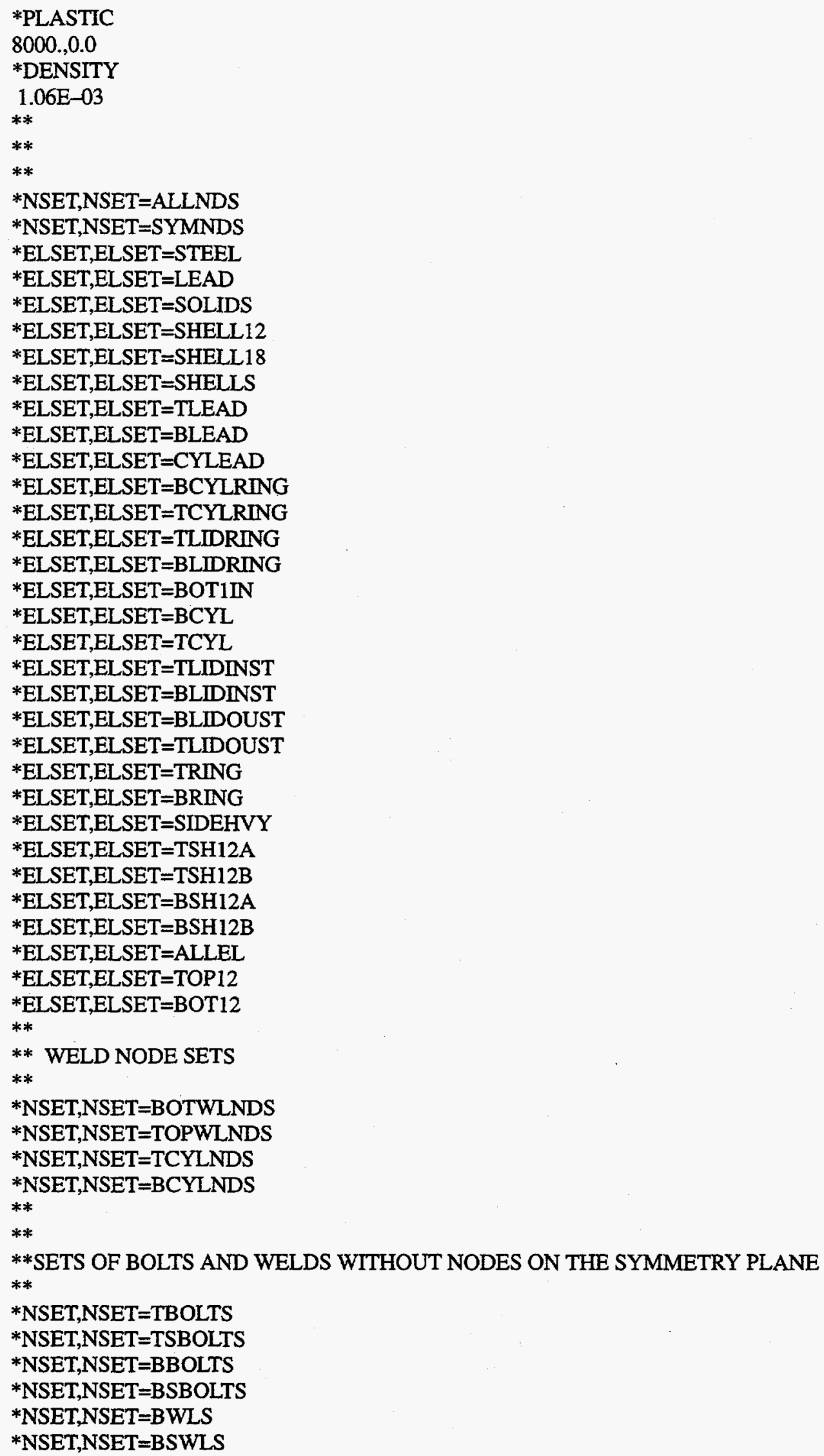




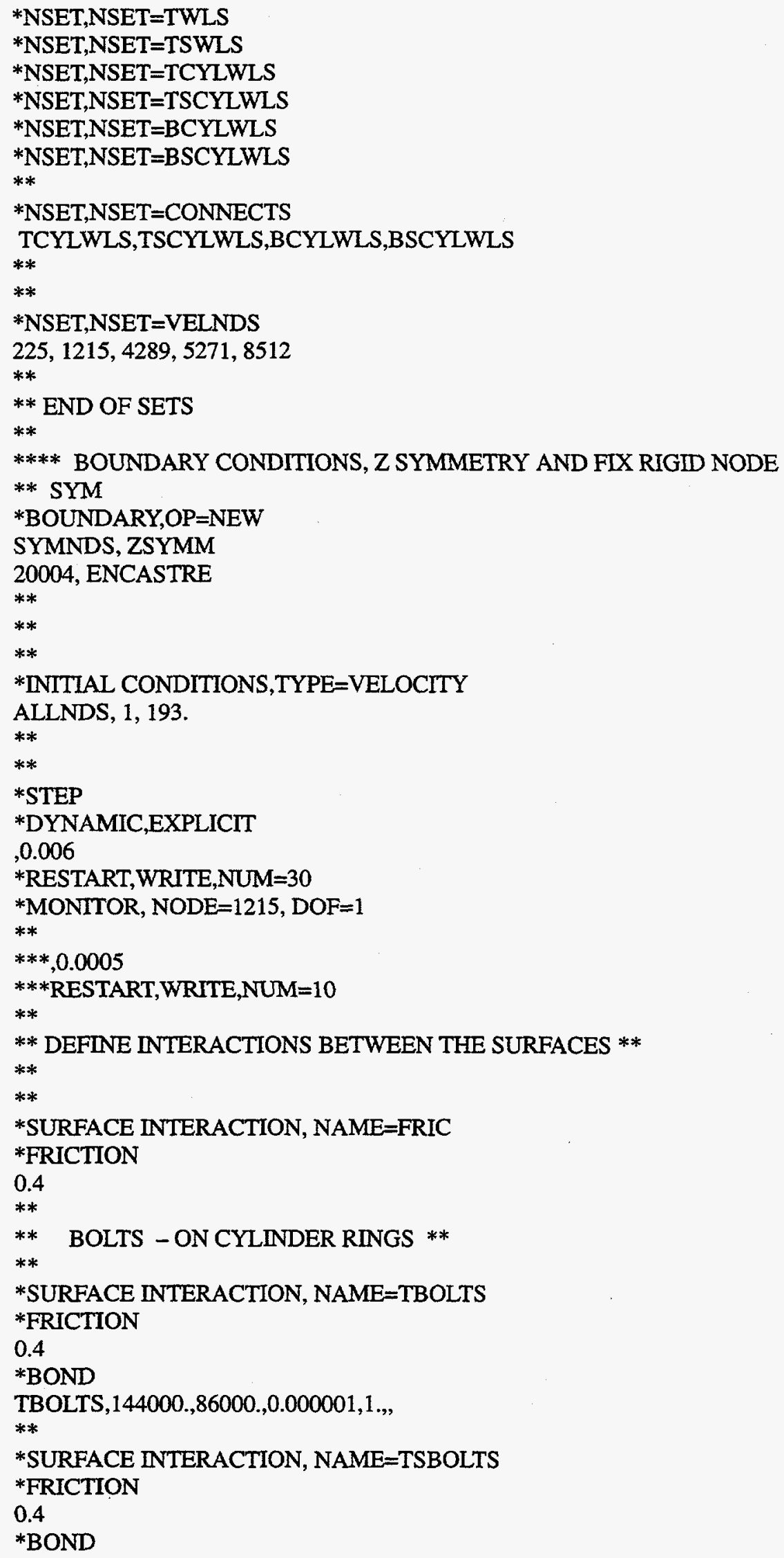


TSBOLTS,72000.,43000.,0.000001,1.,,

**

*SURFACE INTERACTION, NAME=BBOLTS

*FRICTION

0.4

*BOND

BBOLTS,144000.,86000.,0.000001,1.,,

**

*SURFACE INTERACTION, NAME=BSBOLTS

*FRICTION

0.4

*BOND

BSBOLTS, $72000 ., 43000 ., 0.000001,1 .$,

**

** WELDS **

**

*SURFACE INTERACTION, NAME=TLIDWELD

*FRICTION

0.4

*BOND

TOPWLNDS,42500.,42500.,0.000001,1.,,

***

*SURFACE INTERACTION, NAME=BLIDWELD

*FRICTION

0.4

*BOND

BOTWLNDS,42500.,42500.,0.000001,1.,,

**

*SURFACE INTERACTION, NAME=TCYLWELD

*FRICTION

0.4

*BOND

TCYLNDS,42500.,42500.,0.000001,1.,,

**

*SURFACE INTERACTION, NAME=BCYLWELD

*FRICTION

0.4

*BOND

BCYLNDS,42500.,42500.,0.000001,1.,

**

**

** DEFINE THE SURFACES **

**

** LIDS TO CYLINDER SURFACES

**

*SURFACE DEFINITION,NAME=STOP12

TOP12,SNEG

*SURFACE DEFINITION,NAME=STCYL

TCYL,SNEG

**

*SURFACE DEFINITION,NAME=SBOT12

BOT12,SNEG

*SURFACE DEFINITION,NAME=SBCYL

BCYL,SNEG

**

** RIGID SURFACE \& ALL SURFACES FOR DROP SIMULATION 
*SURFACE DEFINITION,NAME=SRIGID RIGID,SPOS

*CONTACT NODE SET,NAME=SALINDS

ALLNDS,

*SURFACE DEFINITION,NAME=SBOTIIN BOT1IN,

*ELSET, ELSET =TOPST

TLIDOUST, TLIDINST

*ELSET, ELSET=BOTST

BLIDOUST, BLIDINST

*SURFACE DEFINITION,NAME=STOPST

TOPST,

*SURFACE DEFINITTON,NAME=SBOTST

BOTST,

**

** RING SURFACES

$* *$

**

*SURFACE DEFINITION,NAME=STLRING TLIDRING,

*SURFACE DEFINITION,NAME=SBLRING BLIDRING,

*SURFACE DEFINITION,NAME=STCRING TCYLRING,

*SURFACE DEFINITION,NAME=SBCRING BCYLRING,

*SURFACE DEFINITION,NAME=STRING TRING,

*SURFACE DEFINITION,NAME=SBRING BRING,

**

** 1/2 INCH OUTER SHELL SURFACES

**

*SURFACE DEFINITION,NAME=STSH12A TSH12A,SNEG

*SURFACE DEFINITION,NAME=STSH12B

TSH12B,SNEG

*SURFACE DEFINITION,NAME=SBSH12A BSH12A,SNEG

*SURFACE DEFINITION,NAME=SBSH12B BSH12B,SNEG

**

$* *$

** 1 INCH COVER PLATE SURFACES

*SURFACE DEFINITION,NAME=STLEAD

TLEAD,

*SURFACE DEFINITION,NAME=SBLEAD

BLEAD,

*SURFACE DEFINITTON,NAME=STLINST TLIDINST,

*SURFACE DEFINITION,NAME=SBLINST BLIDINST,

*SURFACE DEFINITION,NAME=STLOUST TLIDOUST,

*SURFACE DEFINITION,NAME=SBLOUST 


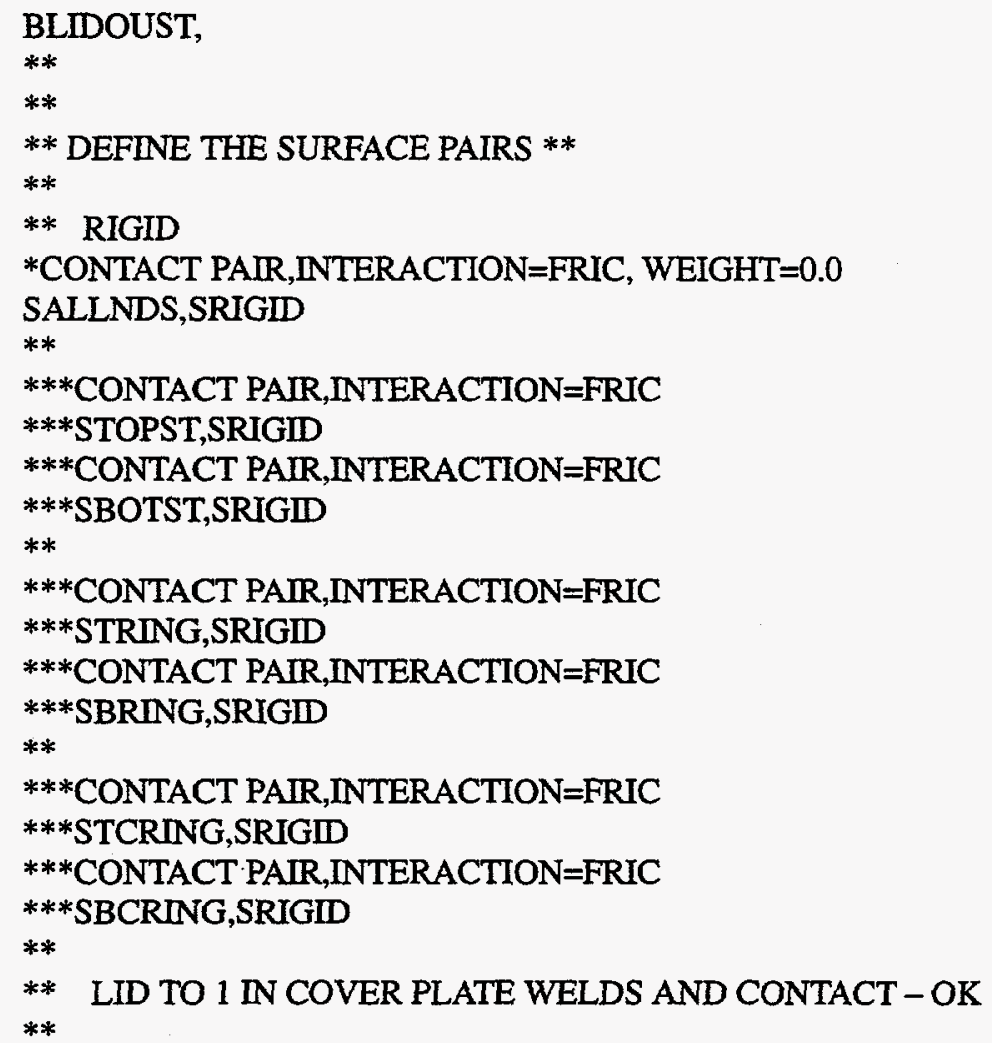


STCRING, STSH12B

*CONTACT PAIR,INTERACTION=FRIC

STLRING, STSH12A

*CONTACT PAIR,INTERACTION=BCYLWELD, WEIGHT $=0.0$

SBCRING, SBSH12B

*CONTACT PAIR,INTERACTION=FRIC

SBLRING, SBSH12A

**

**

$* *$

** SPECIFY OUTPUT

**

$* *$

*HISTORY OUTPUT, TIME=1.E-6

*NODE HISTORY, NSET =VELNDS

U,V,A

*NODE HISTORY, NSET=CONNECTS

U,V,A,RF,BONDSTAT,BONDLOAD

*ENERGY HISTORY

ALLKE, ALLSE, ALLPD, ALLIE, ALLAE, ETOTAL

*FILE OUTPUT, NUM=1

*NODE FILE

$\mathrm{U}$

*END STEP 